\title{
Apoptosis in human liver carcinoma caused by gold nanoparticles in combination with carvedilol is mediated via modulation of MAPK/Akt/mTOR pathway and EGFR/FAAD proteins
}

\author{
RAIMUNDO F. DE ARAÚJO Jr ${ }^{1-3^{*}}$, JONAS B. PESSOA ${ }^{2 *}$, LUIS J. CRUZ ${ }^{4}$, \\ ALAN B. CHAN $^{5}$, EMÍLIO DE CASTRO MIGUEL ${ }^{6}$, RÔMULO S. CAVALCANTE ${ }^{3}$, GERLY ANNE C. BRITO ${ }^{7}$, \\ HELOIZA FERNADA O. SILVA ${ }^{8}$, LUIZ H.S. GASPAROTTO ${ }^{8}$, PAULO M.M. GUEDES ${ }^{9}$ and AURIGENA A. ARAÚJO ${ }^{10}$ \\ ${ }^{1}$ Department of Morphology, ${ }^{2}$ Post Graduation Programme in Structural and Functional Biology, \\ ${ }^{3}$ Post Graduation Programme in Health Science, Federal University of Rio Grande do Norte, Natal 59072-970, RN, Brazil; \\ ${ }^{4}$ Translational Nanobiomaterials and Imaging, Department of Radiology, Leiden University Medical Center; ${ }^{5}$ Percuros B.V., \\ 2333 CL Leiden, The Netherlands; ${ }^{6}$ Department of Physical/Analytical Center/UFC; ${ }^{7}$ Department of Morphology/Postgraduate \\ Program in Morphology/UFC, Fortaleza, CE; ${ }^{8}$ Group of Biological Chemistry and Chemometrics, Institute of Chemistry; \\ ${ }^{9}$ Department of Parasitology and Microbiology and Post Graduation Program in Parasitary Biology; \\ ${ }^{10}$ Department of Biophysics and Pharmacology, Post Graduation Programme in Public Health, \\ Post Graduation Programme in Pharmaceutical Science, Federal University \\ of Rio Grande do Norte, Natal 59072-970, RN, Brazil
}

Received June 29, 2017; Accepted September 21, 2017

DOI: $10.3892 /$ ijo.2017.4179

\begin{abstract}
In cancers, apoptosis signaling pathways and cell survival and growth pathways responsible for resistance to conventional treatments, such as $\mathrm{Pi} 3 \mathrm{~K} / \mathrm{Akt} / \mathrm{mTOR}$ and mitogen-activated protein kinase (MAPK) become dysregulated. Recently, alternative treatments to promote tumor cell death have become important. The present study reports on the antitumor and cytoprotective action of gold nanoparticles (GNPs) and carvedilol in combination and in isolated application. Apoptosis was analyzed by FITC/propidium iodide staining flow cytometry; caspase-3, caspase-8, Bcl-2 and MAPK/ERK activity by immunofluorescence microscopy; gene expression of proteins related to cell death as Akt, mTOR, EGFR, MDR1, survivin, FADD and Apaf, by the
\end{abstract}

Correspondence to: Professor Raimundo Fernandes de Araújo Jr, Department of Morphology, Federal University of Rio Grande do Norte, Campus Universitário Lagoa Nova, CEP 59078-970, Caixa postal 1524, Natal, RN, Brasil

E-mail: araujojr@cb.ufrn.br

Abbreviations: GNPs, gold nanoparticles; Carv, carvedilol; EGFR, epidermal growth factor receptor; Erk, extracellular signal-regulated kinases; FADD, fas-associated protein with death domain; GAPDH, glyceraldehyde 3-phosphate dehydrogenase; MDA, malondialdehyde; MAPK, mitogen activated protein kinases; MDR1, multidrug resistance genes-1; mTOR, mechanistic target of rapamycin; Pi3K, phosphatidylinositide 3-kinases

Key words: apoptosis, cancer, gold nanoparticles, carvedilol, combination real-time PCR; and western blot analysis for MAPK/ERK, Akt and mTOR. Oxidative stress evaluation was performed by reduced glutathione (GSH) and malondialdehyde (MDA) levels. Intracellular GNPs targets were identified by transmission electron microscopy. After exposure to a combination of GNPs $(6.25 \mu \mathrm{g} / \mathrm{ml})$ and carvedilol $(3 \mu \mathrm{M})$, death as promoted by apoptosis was detected using flow cytometry, for expression of pro-apoptotic proteins FADD, caspase-3, caspase- 8 and sub-regulation of anti-apoptotic MAPK/ERK, Akt, mTOR, EGFR and MDR1 resistance. Non-tumor cell cytoprotection with GSH elevation and MDA reduction levels was detected. GNPs were identified within the cell near to the nucleus when combined with carvedilol. The combination of GNP and carvedilol promoted downregulation of anti-apoptotic and drug resistance genes, over-regulation of pro-apoptotic proteins in tumor cells, as well as cytoprotection of non-tumor cells with reduction of apoptosis and oxidative stress.

\section{Introduction}

Cancer, a serious public health problem worldwide, is responsible for countless deaths each year and is currently considered the second leading cause of death on the planet (1-3). In addition, various malignant tumor types do not have effective treatment (4-8), due to the ability of tumor cells to evade death, by presenting changes in apoptosis pathway protein levels (9-11). Changes in other cellular pathway proteins such as Pi3k/Akt/mTOR and MAPK/ERK, which are highly dysregulated in malignant tumors, also corroborate the ability of malignant cells to evade apoptosis death, contributing to chemotherapy resistance (12-14). The expression of multidrug resistance genes, such as MDR1, has been implicated 
as the main cause of chemoresistance $(15,16)$. Furthermore, conventional chemotherapeutic treatments are known for their side-effects on non-tumor cells, such as the strong oxidative stress (17-19).

Moreover, there is a need for alternative treatments that promote apoptosis in tumor cells and yet do not negatively affect normal cells. In this regard, GNPs have been highlighted in the literature as promising agents with large pooling surfaces for various drugs $(20)$, which concentrate on tumor tissues $(21,22)$, are resistant to corrosion and present low toxicity to the biological system (23-25). In addition, various studies reported an effective antitumor action with non toxicity to normal cells (26-29). The antihypertensive carvedilol is often used as a non-selective inhibitor of adrenergic receptors (30), is known for its cardiovascular and antioxidant benefits (31-34) and has recently presented good antitumor activity, such as growth inhibition of neuroblastoma cell lines (35) and rat glioma cell line (36), suppressing migration and invasion of malignant breast cells (37), preventing carcinogenesis in rat epidermal lineages (38) and promoting apoptosis in tumoral hepatic and oral cell linages $(39,40)$. The discovery of new substances and combinations is fundamental to the process of establishing new treatments against cancer (41-43). Combining substances has proven to be extremely effective due to the lower doses used, the decreased adverse effects, and the possibility of acting on different signaling pathways (44-50). In addition, the discovery of substances that promote inhibition of dysregulated pathways such as Pi3k/Akt/mTOR and MAPK/Erk would positively modulate apoptosis in tumor cells $(12,51,52)$. In the present study, we investigated the effects of combined carvedilol and GNPs action on both tumor and non-tumor cells.

\section{Materials and methods}

Reagents. The reagents were purchased as indicated: Dulbecco's modified Eagle's medium (DMEM; Life Technologies, Grand Island, NY, USA); $10 \%$ (v/v) heat-inactivated fetal bovine serum (FBS; Cultilab Materiais para Cultura de Células Ltda, Campinas, Brazil); trypsin/EDTA (ethylenediaminetetraacetic acid) (Gibco-BRL, Life Technologies, Grand Island, NY, USA); cisplatin (citoplax, 50 mg; Bergamo, Taboão da Serra, Brazil); gold nanoparticles GNPs (Institute of Chemical, UFRN, Natal, Brazil); carvedilol (Farmafórmula, Natal, Brazil); gold (III) chloride (30\% wt. in $\mathrm{HCl})$, sodium hydroxide, glycerol, and polyvinylpyrrolidone (PVP, molecular weight, 10,000 Da) were products from Sigma-Aldrich. The synthesis and characterization of GNPs was the described by de Araújo et al (53). GNPs, carvedilol and cisplatin solutions were filtered using a 0.22-mm minipore membrane.

Cell culture. The human cell lines hepatocellular carcinoma (HepG2) and human non-cancerous renal cell line (HEK-293) were purchased from the Culture Collection of the Federal University of Rio de Janeiro (RJCB Collection, Rio de Janeiro, Brazil). HepG2 and Hek-293 cells were maintained in DMEM supplemented with $10 \%(\mathrm{v} / \mathrm{v})$ heat-inactivated FBS.

Cell viability. In order to determine GNP and carvedilol doses to promote and maintain low inhibition in cancer cells, cell viability was determined by trypan blue exclusion assay. The viability was determined at 24 and $48 \mathrm{~h}$ for HepG2 (1x10 cells) at different concentrations of GNPs (1-50 $\mu \mathrm{g} / \mathrm{ml}$, aqueous suspension) and carvedilol [1.5-300 $\mu \mathrm{M}$, dissolved in dimethyl sulfoxide (DMSO) $1 \%$ ]. The cells were placed into 6-well plates. Briefly, cell aliquots were mixed with the same volume $0.5 \%(\mathrm{w} / \mathrm{v})$ trypan blue and incubated at room temperature for $5 \mathrm{~min}$. The number of viable cells was calculated using a hemocytometer.

Annexin $V$ and propidium iodide staining. The apoptotic assay was conducted according to Araújo Jr et al (54). HepG2 and HEK-293 were plated in 6 -well plates $\left(2 \times 10^{5}\right.$ cells/well) with $2 \mathrm{ml} \mathrm{medium} /$ well. After $24 \mathrm{~h}$, concentrations of GNPs (3 and $6.25 \mu \mathrm{g} / \mathrm{ml})$, cisplatin $(15 \mu \mathrm{g} / \mathrm{ml})$ and carvedilol $(1.5$ and $3 \mu \mathrm{M})$ were added ( 24 and $48 \mathrm{~h}$ ), respectively. In parallel, control cells were maintained in culture medium without GNPs, carvedilol or cisplatin. For observation of combined action, the cells were treated with GNPs (3 and $6.25 \mu \mathrm{g} / \mathrm{ml}$ ) and at $24 \mathrm{~h}$ treated with carvedilol $(1.5$ and $3 \mu \mathrm{M})$. After another $24 \mathrm{~h}$, they were analyzed. The cells were then assayed using the Annexin V-FITC/PI apoptosis detection kit I (BD Biosciences, San Diego, CA, USA). Annexin V-FITC and propidium iodide (PI) were added to the cellular suspension according to the manufacturer's instructions. A total of $1 \times 10^{6}$ cells from each sample was then analyzed by FACSCalibur cytometer (BD Biosciences, Franklin Lakes, NJ, USA), and FlowJo software (BD Biosciences). Annexin V-FITCpositive/PI-negative cells were identified as cells in the early stages of apoptosis, while Annexin V-FITC-positive/PI-positive cells were identified as cells in the late stages of apoptosis, or as cells undergoing necrosis.

Glutathione (GSH) levels. Antioxidant GSH levels in cell lines were measured [adapted from Rahman et al (55) and Costa et al (56)]. HepG2 and Hek-293 were plated in 6-well plates $\left(2 \times 10^{5}\right.$ cells/well) with $2 \mathrm{ml}$ medium/well. After $24 \mathrm{~h}$, GNPs $(6.25 \mu \mathrm{g} / \mathrm{ml})$ was added and after $24 \mathrm{~h}, 3 \mu \mathrm{M}$ carvedilol. A homogenate of cells (100 $\mu \mathrm{l}$ of cell in $500 \mu \mathrm{l}$ EDTA $0.02 \mathrm{M})$ were added to $320 \mu \mathrm{l}$ of distilled water and $80 \mu \mathrm{l}$ of $50 \%$ trichloroacetic acid (TCA). Samples were centrifuged at 3,000 rpm for $15 \mathrm{~min}$ at $4^{\circ} \mathrm{C}$. The supernatant $(100 \mu \mathrm{l})$ was added to $200 \mu \mathrm{l}$ of $0.4 \mathrm{M}$ Tris buffer at $\mathrm{pH} 8.9$ and $20 \mu \mathrm{l}$ of $0.01 \mathrm{M} 5,5$ '-dithiobis (2-nitrobenzoic acid) (DTNB). The absorbance of each sample was measured at $420 \mathrm{~nm}$, in a spectrophotometric/microplate reader Polaris and the results were reported as units of GSH per milligram.

Malondialdehyde levels. Malondialdehyde (MDA) is an end product of lipid peroxidation. To quantify the increase in free radicals in non-cancer (HEK-293) and cancer (HepG2) cells, MDA content was measured via the assay described by Esterbauer and Cheeseman (57). Cell samples were suspended in buffer; Tris $\mathrm{HCl} \mathrm{1:5} \mathrm{(w/v),} \mathrm{and} \mathrm{minced} \mathrm{with} \mathrm{scissors} \mathrm{for}$ $15 \mathrm{sec}$ on an ice-cold plate. The resulting suspension was homogenized for $2 \mathrm{~min}$ with an automatic Potter homogenizer and centrifuged at $11,000 \mathrm{rpm}$ at $4^{\circ} \mathrm{C}$ for $10 \mathrm{~min}$. The supernatants were assayed in order to determine the MDA content. The absorbance of each sample was measured at $586 \mathrm{~nm}$. The results are expressed as nanomoles of MDA per cell.

Immunofluorescence, Bcl-2, MAPK/ERK, caspase-3 and caspase-8 activity. HepG2 cells were plated on glass 
coverslips in 24 -well plates $\left(5 \times 10^{4}\right.$ cells/well). After $24 \mathrm{~h}$, they were treated with the GNPs $(6.25 \mu \mathrm{g} / \mathrm{ml})$, cisplatin $(15 \mu \mathrm{g} / \mathrm{ml})$ and carvedilol $(3 \mu \mathrm{M})$ for $48 \mathrm{~h}$. For combined action, we used GNPs $(6.25 \mu \mathrm{g} / \mathrm{ml})+$ carvedilol $(3 \mu \mathrm{M})$. The cells were then washed, and fixed with paraformaldehyde, permeabilized by Triton-X, and incubated with anti-Bcl-2 mouse polyclonal antibody, rabbit polyclonal anti-caspase-3 antibody (Abcam, San Francisco, CA, USA), rabbit anti-caspase-8 monoclonal antibody (Santa Cruz Biotechnology, Santa Cruz, CA, USA), and monoclonal mouse antibody anti-MAPK/ERK (Invitrogen, Carlsbad, CA, USA) diluted 1:500 in phosphate-buffered saline (PBS) containing bovine serum albumin (BSA; 5\%; Life Technologies do Brasil Ltda, São Paulo, Brazil) for $1 \mathrm{~h}$ at RT in a humid atmosphere. The primary antibody was detected with Alexa Fluor 488 goat anti-rabbit or anti-mouse secondary antibody (Abcam), and 4',6-diamidino-2-phenylindole (Life Technologies do Brasil Ltda) was used for nuclear staining. The immunostained coverslips were examined under Axio Observer z.1, inverted fluorescence and brightfield.

Fluorescent images were obtained on a Carl Zeiss Laser Scanning Microscope (LSM 710, 20X objectives; Carl Zeiss, Oberkochen, Germany). Negative controls and treated groups were included in each batch of samples. Cell reactivity in all groups (negative, GNPs, carvedilol, GNPs + carvedilol and cisplatin) was assessed by computerized densitometric analysis of the captured digital images with the aforementioned immunofluorescence microscope. Average densitometric values were calculated in ImageJ software (http://rsb.info.nih.gov/ij/). Contrast index measurements were obtained from the formula [(selected area x 100)/total area] after removal of background in regions of interest (three samples per group).

Real-time PCR. HepG2 cells were plated in 6-well plates ( $2 \times 10^{5}$ cells/well) with $2 \mathrm{ml}$ medium/well. After $24 \mathrm{~h}$, concentrations of gold nanoparticles $(6.25 \mu \mathrm{g} / \mathrm{ml})$, cisplatin $(15 \mu \mathrm{g} / \mathrm{ml})$ and carvedilol $(3 \mu \mathrm{M})$ were added for $48 \mathrm{~h}$. For combined action, GNPs $(6.25 \mu \mathrm{g} / \mathrm{ml})+(3 \mu \mathrm{M})$ carvedilol was used. The cells were collected with cell scrapers and total RNA was isolated from cells using TRIzol reagent. The total RNA was extracted from cell samples using RNeasy Mini kit (Qiagen, Tokyo, Japan) from QIAcube following the manufacturer's guidelines. The total RNA extracted underwent reverse transcriptase activity using the High capacity RNA-to-cDNA kit (Applied Biosystems, Ltd., Tokyo, Japan). Real-time quantitative PCR analyses of EGFR, Akt, mTOR, survivin, MDR-1, FADD, Apaf-1 and GAPDH mRNAs were performed with SYBR-Green Mix in the Applied Biosystems ${ }^{\circledR} 7500$ FAST system (Applied Biosystems, Foster City, CA, USA), according to a standard protocol with the following primers: $G A P D H$ (forward, 5'-AAC TTT GGC ATC GTG GAA GG-3' and reverse, 5'-GTG GAT GCA GGG ATG ATG TTC-3', annealing primer temperature, $60^{\circ} \mathrm{C}$ ); EGFR (forward, 5'-TGA TAG ACG CAG ATA GTC GCC-3' and reverse, 5'-TCA GGG CAC GGT AGA AGT TG-3', annealing primer temperature, 56. $6^{\circ} \mathrm{C}$ ); Akt (forward, 5'-ACG GCA TGG ACT TTA CCA AG-3' and reverse, 5'-GCG GGT GAA AGA CAG GAA TA-3', annealing primer temperature, $55^{\circ} \mathrm{C}$ ); mTOR (forward, 5'-TTG AGG TTG CTA TGA CCA GAG AGA A-3' and reverse, 5'-TTA CCA GAA AGG ACA CCA GCC AAT G-3', annealing primer temperature, $58.3^{\circ} \mathrm{C}$ ); survivin (forward, 5'-TAC AGC TTC
GCT GGA AAC CT-3' and reverse, 5'-AGC CCG GAT GAT ACA AAC AG-3', annealing primer temperature, $55.6^{\circ} \mathrm{C}$ ); MDR1 (forward, 5'-GTG TGG TGA GTC AGG AAC CTG TAT-3' and reverse, 5'-TCT CAA TCT CAT CCA TGG TGA CA-3', annealing primer temperature, $57^{\circ} \mathrm{C}$ ); FADD (forward, 5'-TCT CCA ATC TTT CCC CAC AT-3' and reverse, 5'-GAG CTG CTC GCC TCC CT-3', annealing primer temperature, $58.7^{\circ} \mathrm{C}$ ); and Apaf-1 (forward, 5'-CCT CTC ATT TGC TGA TGT CG-3' and reverse, 5'-TCA CTG CAG ATT TTC ACC AGA-3', annealing primer temperature, $56.9^{\circ} \mathrm{C}$ ). The experiments were performed in triplicate. The standard PCR conditions were as follow: $50^{\circ} \mathrm{C}$ for $2 \mathrm{~min}$ and $95^{\circ} \mathrm{C}$ for $10 \mathrm{~min}$, followed by 40 of 30 -sec cycles at $94^{\circ} \mathrm{C}$, a variable annealing primer temperature for $30 \mathrm{sec}$ and at $72^{\circ} \mathrm{C}$ for $1 \mathrm{~min}$. Mean $\mathrm{Ct}$ values were used to calculate the relative expression levels of the target genes for the experimental groups as relative to those in the negative control group; expression data were normalized relative to the housekeeping gene $G A P D H$ using the $2^{-\Delta \Delta \mathrm{Ct}}$ formula.

Western blot analysis. Cells (HepG2) were lysed in buffer [Tris-HCl 50 mM, NaCl 150 mM, Triton X-100 1\%, EDTA $1 \mathrm{mM}$, sodium pyrophosphate $20 \mathrm{mM}, \mathrm{pH} 7.4$ containing a protease inhibitors cocktail (Roche), NaF (10 mM), DTT (1 mM), PMSF (0.1 mM) and sodium vanadate $(1 \mathrm{mM})]$ on ice. To confirm equal loadings, total protein concentration was determined using the Bradford method (Bio-Rad Laboratories, Hercules, CA, USA). Proteins were resolved using SDS-PAGE and then transferred to a polyvinylidene diflouride (PVDF) membrane. Non-specific binding sites on the membrane were blocked using 5\% non-fat skimmed milk and incubated with the primary antibody anti-Akt (1:500; Abcam), anti-mTOR (1:500; Abcam), and MAPK/ERK (1:200; Abcam), overnight at $4{ }^{\circ} \mathrm{C}$, followed by incubation with the appropriate secondary antibodies: Akt $\alpha$-rat peroxidase 1:1,000; mTOR-rabbit peroxidase 1:2,000 and MAPK/ERK $\alpha$-rat peroxidase 1:1,000. Proteins were detected using the ECL Plus kit (Perkin-Elmer, San Jose, CA, USA).

Transmission electronic microscopy (TEM). Cells (HepG2) at a density of $3 \times 10^{5}$ were plated into (GNPs sensitized and treated) 6-well plates, and after $48 \mathrm{~h}$ were collected with trypsin, centrifuged at $1,500 \mathrm{rpm}$ for $5 \mathrm{~min}$, and washed with PBS. The cell pellet was fixed with $2.5 \%$ glutaraldehyde + paraformaldehyde $4 \%$ + sodium cacodylate buffer $(0.1 \mathrm{M})$ for $4 \mathrm{~h}$ at $4-8^{\circ} \mathrm{C}$. Afterwards, the samples were washed in $0.05 \mathrm{M}$ sodium cacodylate $(3 \times 30 \mathrm{~min})$, post-fixed in $1 \%$ $\mathrm{OsO}_{4}+1 \%$ potassium ferrocyanide $(2 \mathrm{~h})$, washed again $(3 \mathrm{x})$ with $0.05 \mathrm{M}$ sodium cacodylate $(3 \times 30 \mathrm{~min})$, and then serially dehydrated in ethanol 50, 70, 90 and 100, for $30 \mathrm{~min}$ each. Polymerization of the resin was performed at $60^{\circ} \mathrm{C}$ for $48 \mathrm{~h}$. Finally, ultramicrotomy was performed followed by staining (uranyl acetate $1 \%+1 \%$ lead citrate $1 \mathrm{~h}$ ), and electron microscope visualization (Tescan transmission, Vega 3 model).

Statistical analysis. All experiments were performed in triplicate, and the significant differences between the groups were calculated using the analysis of variance and the Bonferroni's test, as indicated. A $\mathrm{P}<0.05$ was considered statistically significant. 

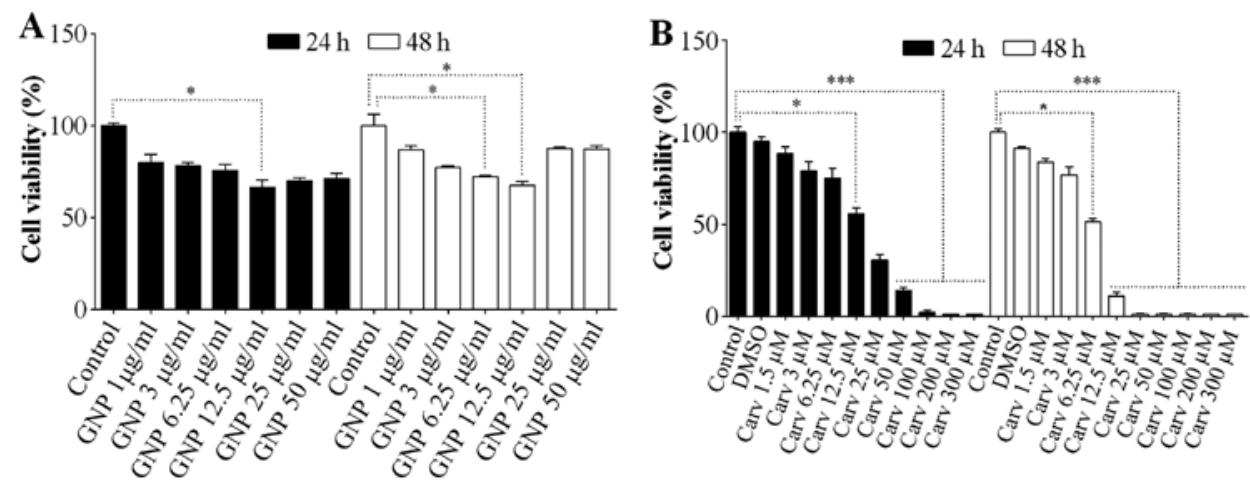

Figure 1. Cell viability to determine the cell growth. (A) Effect of different doses of GNPs on hepatic tumor cells (HepG2) at 24 and $48 \mathrm{~h}$. The $12.5 \mu \mathrm{g} / \mathrm{ml}$ dose caused greater cellular growth inhibition at both times. (B) Effect of different doses of carvedilol on hepatic tumor cells (HepG2) at 24 and 48 h. Doses $>6.25 \mu \mathrm{M}$ promoted strong inhibition of cell growth. ${ }^{*} \mathrm{P}<0.05 ;{ }^{* * *} \mathrm{P}<0.001$.

A

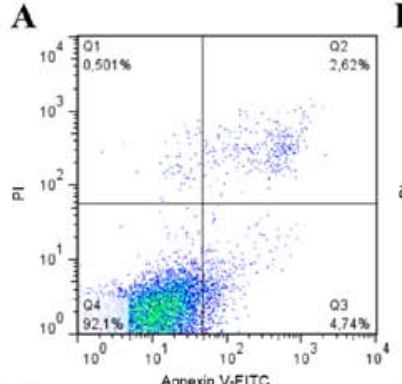

E

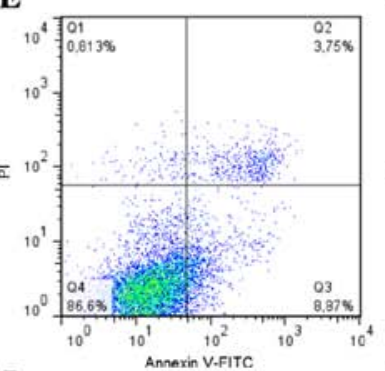

I
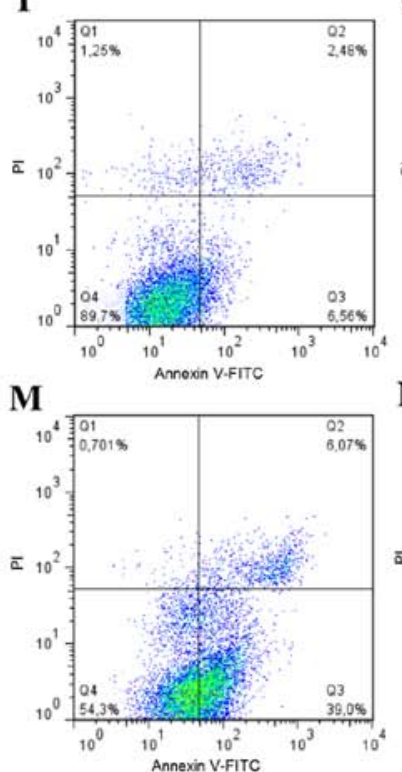

B

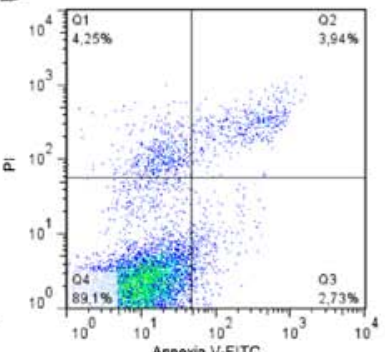

F

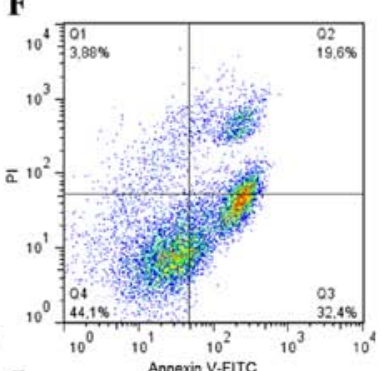

J

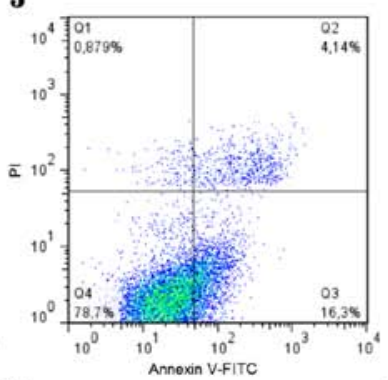

C

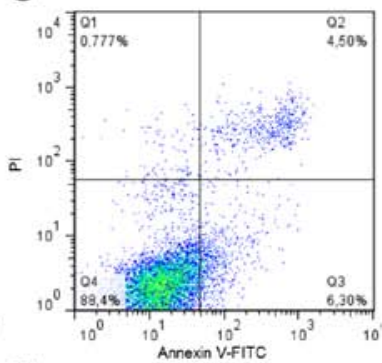

G

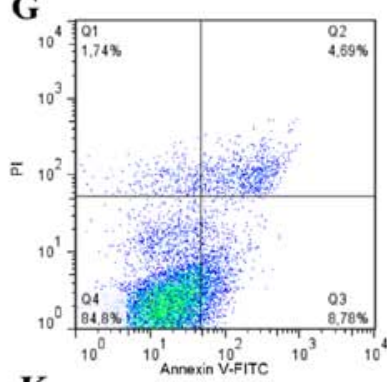

K

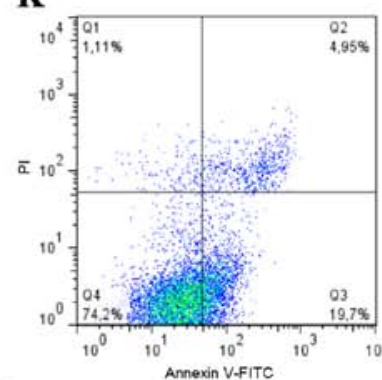

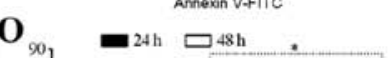

D

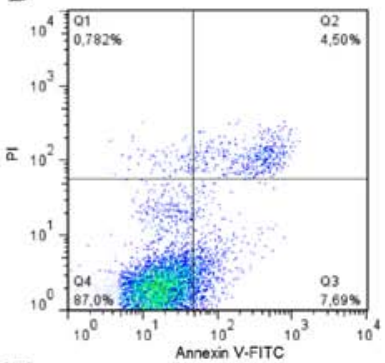

H

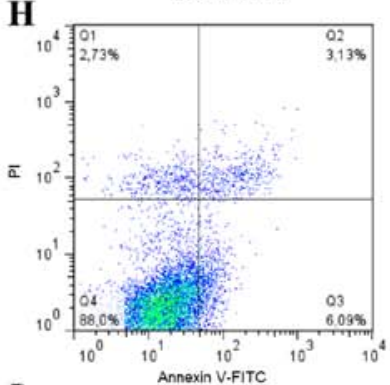

L

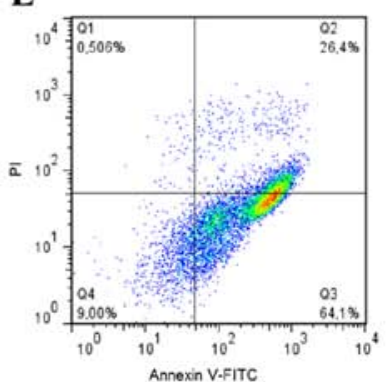

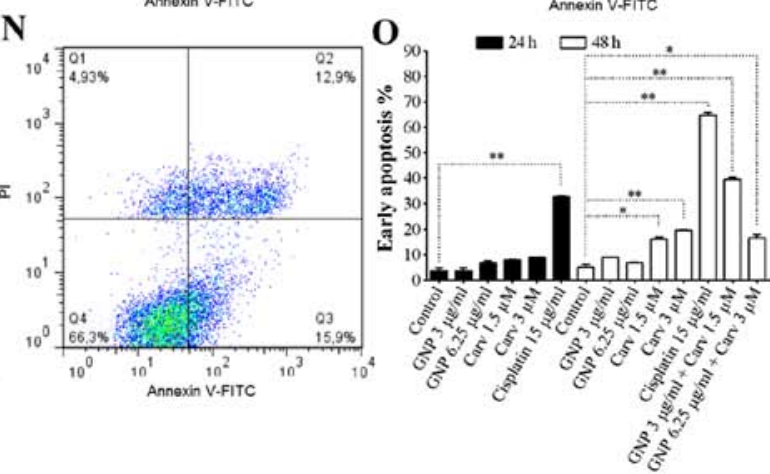

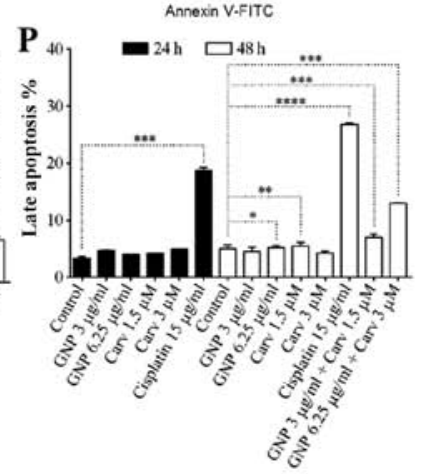

Figure 2. Flow cytometry to determine the cell death for apoptosis. Effect of different doses of GNPs, carvedilol, and cisplatin on early and late apoptosis in HepG2 cells. (A-F) At $24 \mathrm{~h}$ and (G-N) at $48 \mathrm{~h}$. Control (A and G), GNPs $3 \mu \mathrm{g} / \mathrm{ml}$ (B and H), GNPs $6.25 \mu \mathrm{g} / \mathrm{ml}$ (C and I), Carv 1.5 $\mu \mathrm{M}$ (D and J), Carv $3 \mu \mathrm{M}$ (E and $\mathrm{K})$, cisplatin $15 \mu \mathrm{g} / \mathrm{ml}(\mathrm{F}$ and L). GNPs $3 \mu \mathrm{g} / \mathrm{ml}+$ Carv $1.5 \mu \mathrm{M}(\mathrm{M})$ and GNPs $6.25 \mu \mathrm{g} / \mathrm{ml}+\mathrm{Carv} 3 \mu \mathrm{M}(\mathrm{N})$. (O) Early apoptosis and (P) late apoptosis. ${ }^{*} \mathrm{P}<0.05,{ }^{* *} \mathrm{P}<0.01$ and ${ }^{* * *} \mathrm{P}<0.001$. 
A

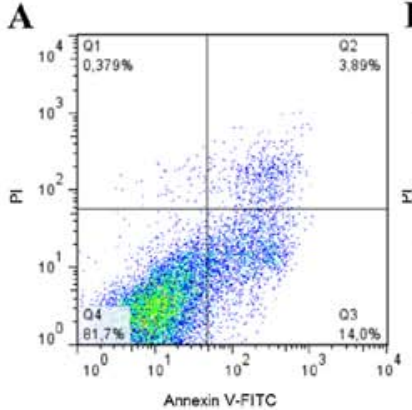

E

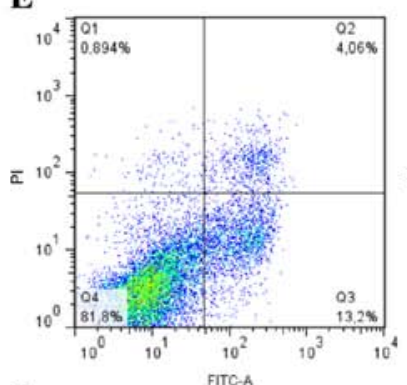

I

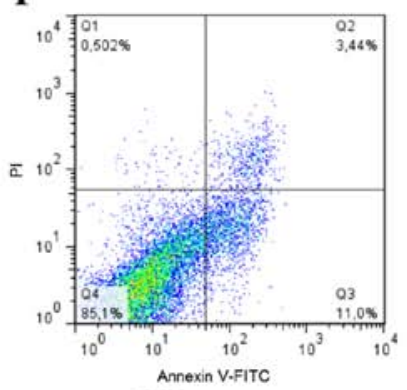

M

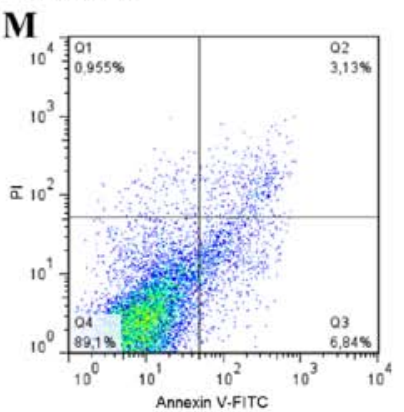

B

F

$\mathbf{J}$
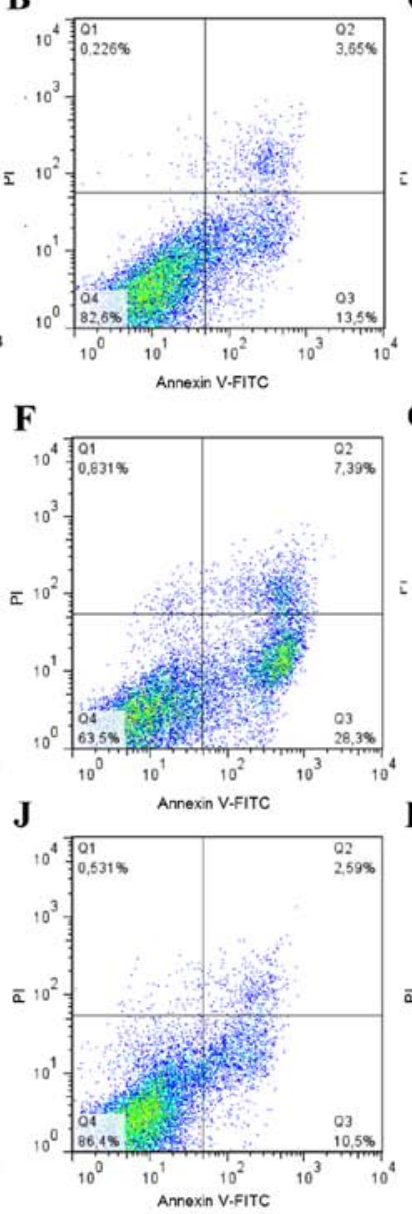

$\mathbf{N}$

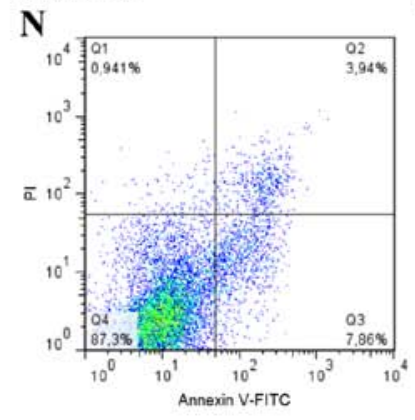

C

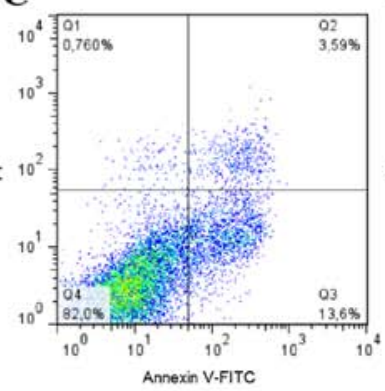

G

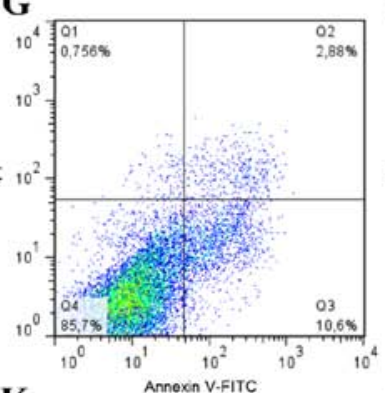

K

$\mathbf{K}$

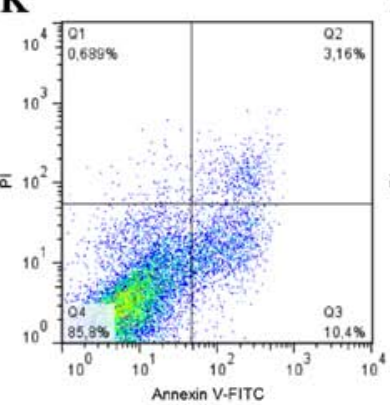

D

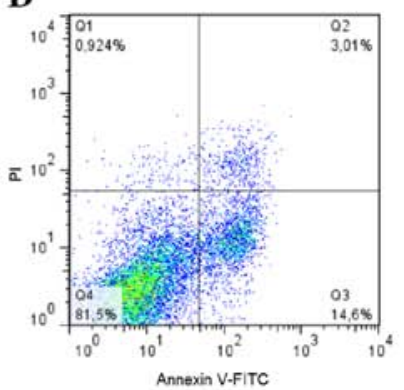

$\mathbf{H}$

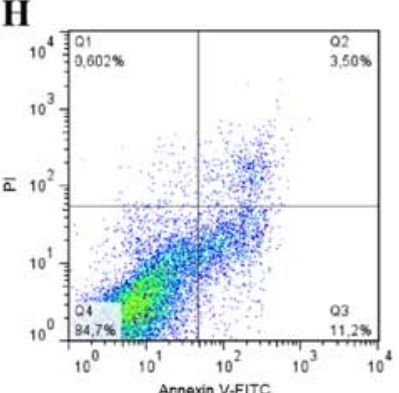

$\mathbf{L}$

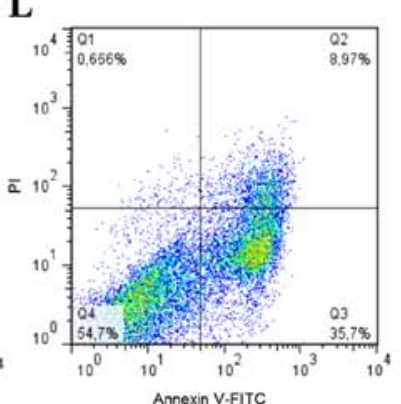

0

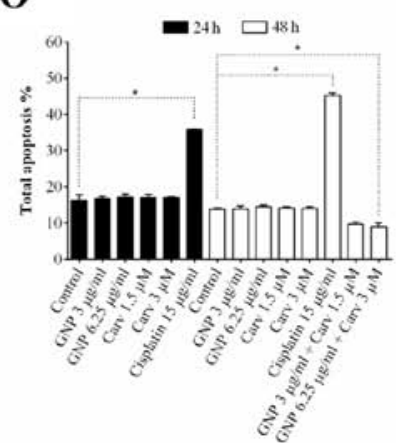

Figure 3. Flow cytometry to determine cell death by apoptosis. Effect of different doses of GNPs, carvedilol, and cisplatin on early and late apoptosis in HEK293 cells at $24 \mathrm{~h}(\mathrm{~A}-\mathrm{F})$ and $48 \mathrm{~h}(\mathrm{G}-\mathrm{N})$. Control (A and G), GNPs $3 \mu \mathrm{g} / \mathrm{ml}$ (B and H), GNPs $6.25 \mu \mathrm{g} / \mathrm{ml}(\mathrm{C}$ and I), Carv $1.5 \mu \mathrm{M}$ (D and J), Carv $3 \mu \mathrm{M}$ (E and K), cisplatin $15 \mu \mathrm{g} / \mathrm{ml}$ (F and L). GNPs $3 \mu \mathrm{g} / \mathrm{ml}+\operatorname{Carv} 1.5 \mu \mathrm{M}(\mathrm{M})$ and GNPs $6,25 \mu \mathrm{g} / \mathrm{ml}+\operatorname{Carv} 3 \mu \mathrm{M}$ (N). (O) Total apoptosis. "P<0.05.

\section{Results}

Cell viability. The GNPs doses 1,3 and $6.25 \mu \mathrm{g} / \mathrm{ml}$, at $24 \mathrm{~h}$ (Fig. 1A) promoted low inhibition of cellular viability. The other GNPs doses promoted greater cellular growth inhibition, when compared to lower doses. The most significant was $12.5 \mu \mathrm{g} / \mathrm{ml}(\mathrm{P}<0.05)$. At $48 \mathrm{~h}$, GNPs doses of 3 and $6.25 \mu \mathrm{g} / \mathrm{ml}$ maintained low inhibition similar to that at $24 \mathrm{~h}$ (Fig. 1A), and for GNPs doses of 1, 25 and $50 \mu \mathrm{g} / \mathrm{ml}$, there was cellular growth when compared to the same doses at $24 \mathrm{~h}$. The carvedilol doses that promoted low inhibition of cellular viability were 1.5 and $3 \mu \mathrm{M}$ at $24 \mathrm{~h}$ (Fig. 1B). The other carvedilol doses promoted greater cellular growth inhibition
$(\mathrm{P}<0.001)$. At $48 \mathrm{~h}$, the 1.5 and $3 \mu \mathrm{M}$ carvedilol doses maintained low inhibition (Fig. 1B). The other doses of carvedilol promoted greater cellular growth inhibition $(\mathrm{P}<0.001)$. DMSO at $1 \%$ was used as the carvedilol vehicle.

Detection of apoptosis, by flow cytometer. For HepG2 cells, combined treatment (GNP $6.25 \mu \mathrm{g} / \mathrm{ml}+$ carvedilol $3 \mu \mathrm{M})$ induced early $(\mathrm{P}<0.05)$ and late $(\mathrm{P}<0.001)$ apoptosis at $48 \mathrm{~h}$ (Fig. 2O-P). The isolated dose of carvedilol $(3 \mu \mathrm{M})$ induced early apoptosis at $48 \mathrm{~h}$ (Fig. 2O; P<0.01). GNPs $(6.25 \mu \mathrm{g} / \mathrm{ml})$ induced late apoptosis at $48 \mathrm{~h}, \mathrm{P}<0.05$. Doses of GNPs and carvedilol did not induce statistically significant apoptosis in non-tumor cells (Fig. 3). Combined treatment 

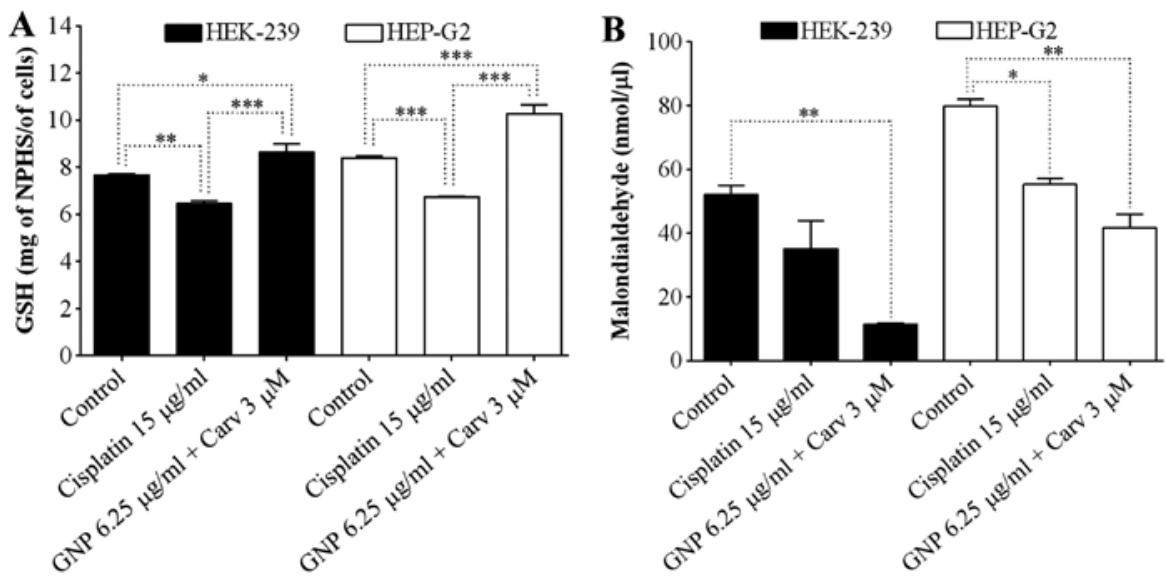

Figure 4. Oxidative stress markers. (A) GSH measurement, important protein in balance of oxidative stress. The combined treatment modulated GSH levels on HEK-293 ( ${ }^{*} \mathrm{P}<0.05 ;{ }^{* *} \mathrm{P}<0.01$ and $\left.^{* * * *} \mathrm{P}=0.0003\right)$ and HepG2 $\left({ }^{*} \mathrm{P}<0.05 ;{ }^{* *} \mathrm{P}<0.01\right.$ and $\left.{ }^{* * * *} \mathrm{P}<0.0001\right)$. (B) MDA measurement, indirect marker of oxidative stress. After combined treatment with GNPs and Carv, there was a reduction of the statistically significant levels of malondialdehyde in tumor and non-tumoral lines. ${ }^{*} \mathrm{P}<0.05 ;{ }^{* *} \mathrm{P}<0.01$.

$\mathbf{A}$
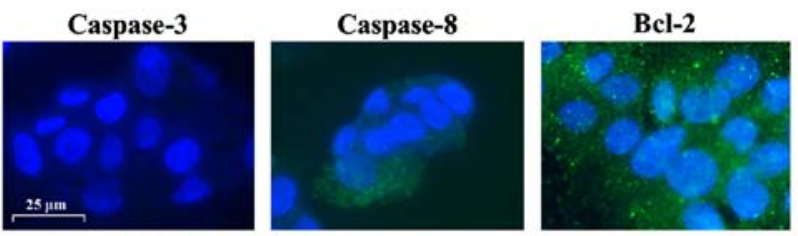

MAPK/ERK

Control
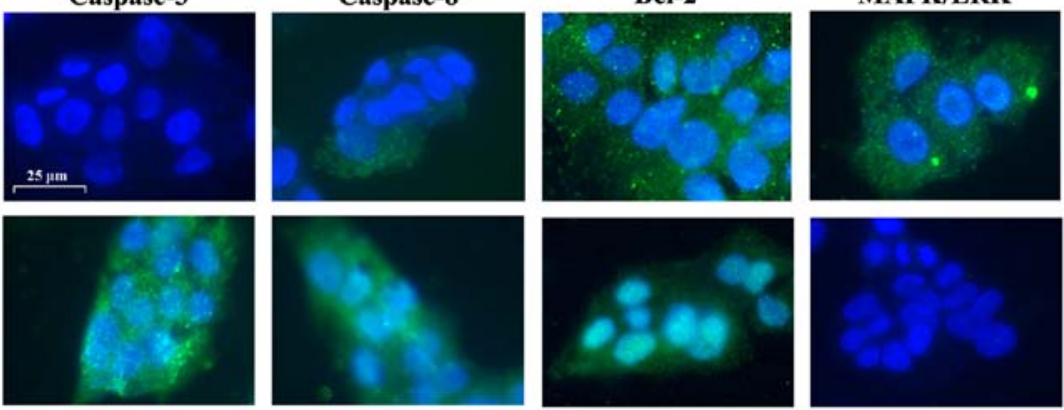

GNP 6.25 $\mu \mathrm{g} / \mathrm{ml}$
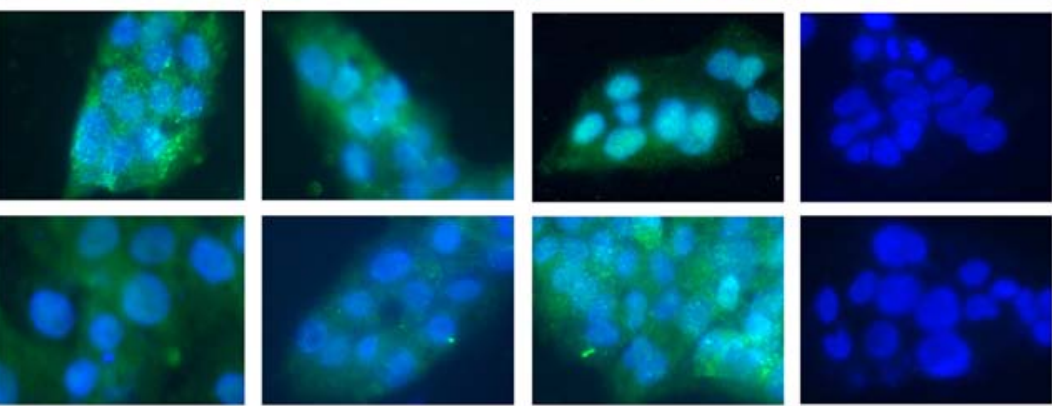

Carvedilol $3 \mu \mathrm{M}$

Cisplatin $15 \mu \mathrm{g} / \mathrm{ml}$
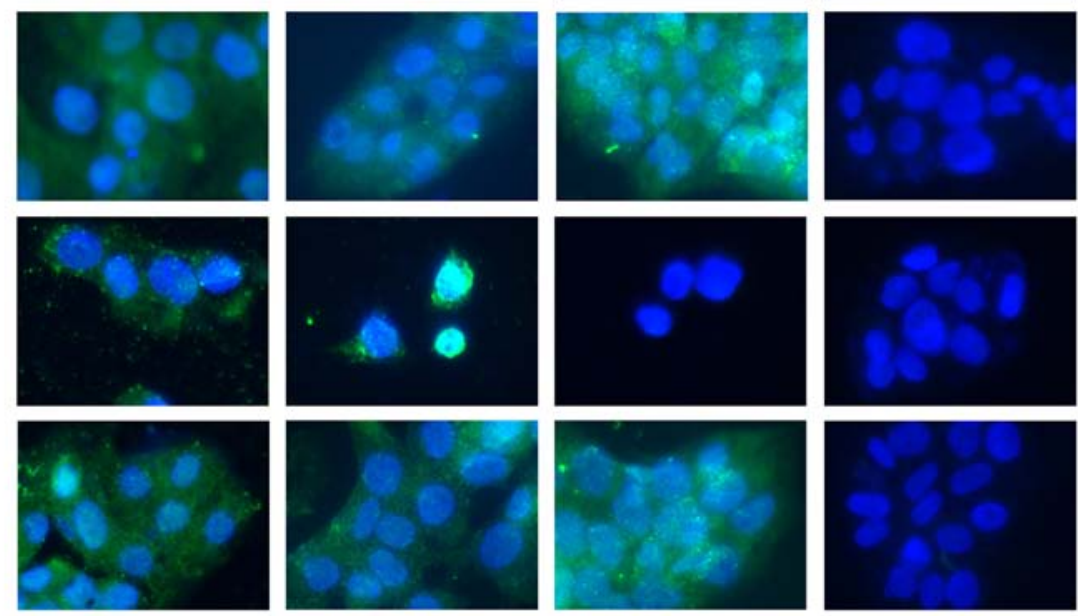

GNP + Carv

$6.25 \mu \mathrm{g} / \mathrm{ml}+3 \mu \mathrm{M}$
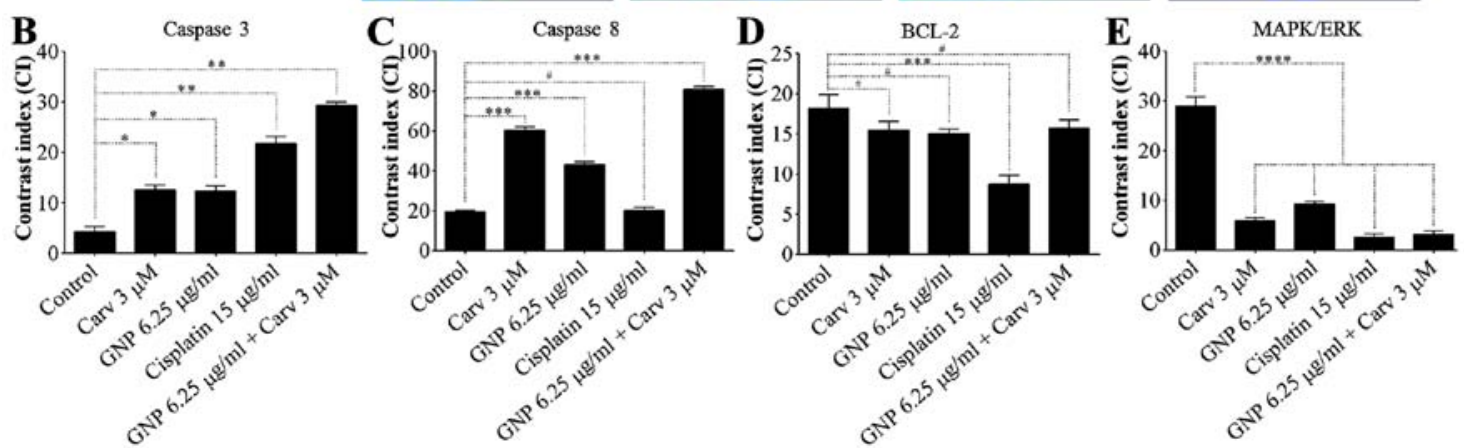

Figure 5. Detection of caspase-3, caspase-8, Bcl-2 and MAPK/ERK. HepG2 cells stained with DAPI (blue), anti-caspase-3, anti-caspase-8, anti-Bcl-2, and anti-MAPK/ERK antibodies (green) (A). Caspase-3 and caspase-8 were detected in all treated groups, yet MAPK/ERK was not. Bcl-2 did not alter expression. Contrast index for caspase-3, ${ }^{*} \mathrm{P}<0.05$ and ${ }^{* *} \mathrm{P}<0.01$ (B); caspase- $8,{ }^{* * * *} \mathrm{P}<0.001$ and ${ }^{*} \mathrm{P}>0.05$ (C); Bcl-2, ${ }^{\#} \mathrm{P}>0.05$ and ${ }^{* * * *} \mathrm{P}<0.001$ (D) and MAPK/ERK, ${ }_{* * * *} \mathrm{P}<0.0001$ (E). All groups treated with GNPs + Carv showed high immunoreactivity for caspase-3, caspase-8 and low immunoreactivity for MAPK/ERK. 

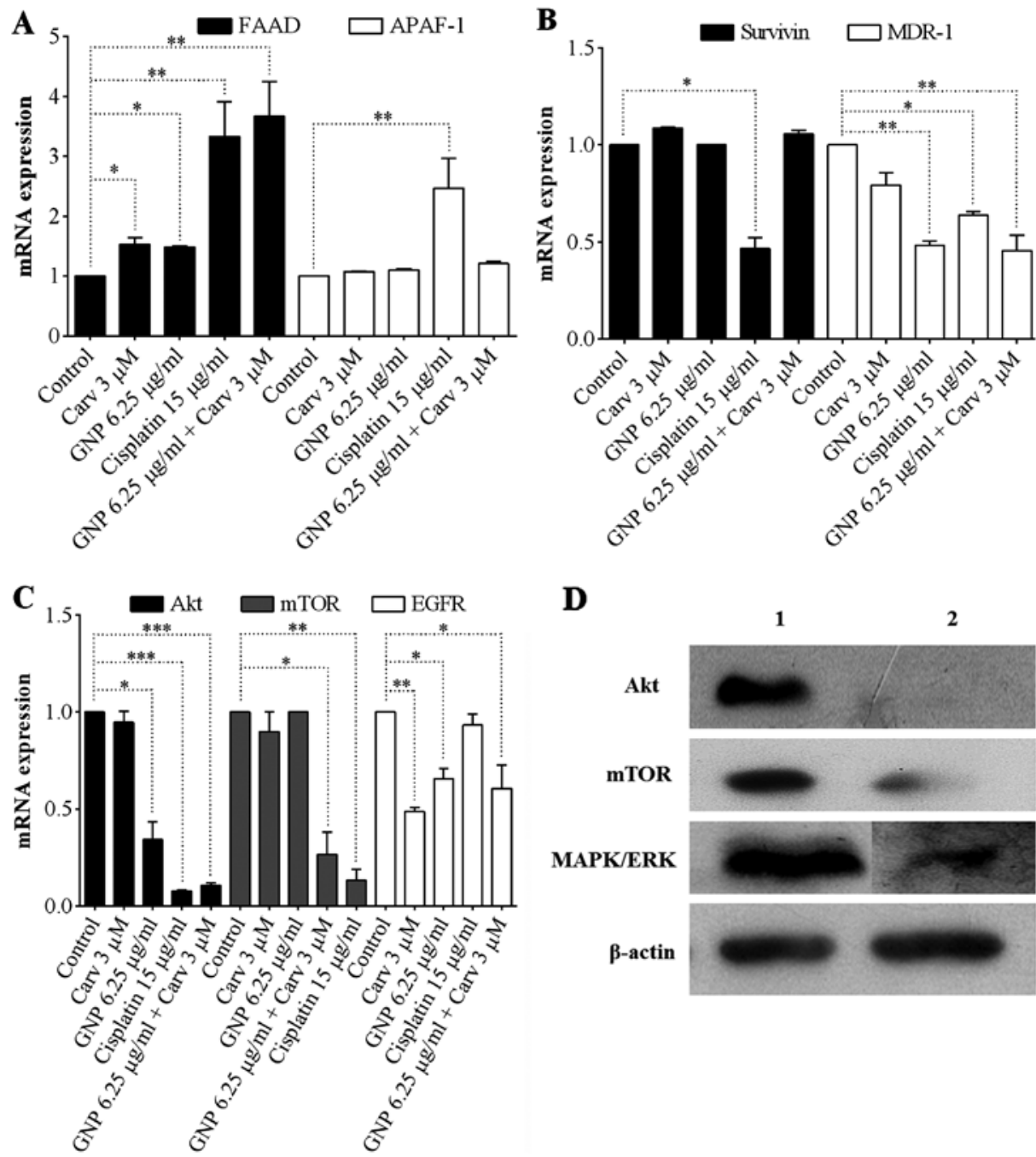

Figure 6. Gene and protein expression. Relative expression of genes related to survival and tumor resistance by real-time PCR. (A) FADD and Apaf-1, ${ }^{*} \mathrm{P}<0.05$ and ${ }^{* * *} \mathrm{P}<0.01$; (B) surviving and MDR $1,{ }^{*} \mathrm{P}<0.05$ and ${ }^{* * *} \mathrm{P}<0.01$; (C) EGFR, Akt and mTOR, ${ }^{*} \mathrm{P}<0.05,{ }^{* * *} \mathrm{P}<0.01,{ }^{* * * *} \mathrm{P}<0.001$. (D) Western blot analysis of proteins related to survival and tumor proliferation. After exposure to the GNPs and carvedilol combination, there was a large decrease in the protein levels of Akt. mTOR and MAPK/ERK have a good reduction. $\beta$-actin was used as internal control. Lane 1, Control; lane 2, GNP $6.25 \mu \mathrm{g} / \mathrm{ml}+\mathrm{Carv} 3 \mu \mathrm{M}$.

(GNP $6.25 \mu \mathrm{g} / \mathrm{ml}+$ carvedilol $3 \mu \mathrm{M})$ promoted cytoprotection $(\mathrm{P}<0.05$; Fig. 3O). When HepG2 and HEK-293 cells were treated with $15 \mu \mathrm{g} / \mathrm{ml}$ cisplatin, apoptosis was detected at 24 and $48 \mathrm{~h}$ after treatment (Figs. $2 \mathrm{~F}$ and $\mathrm{L}$ and $3 \mathrm{~F}$ and $\mathrm{L}$, respectively). The goal of using a non-tumor cell is to have as a control a non-tumoral lineage to analyze its behavior against the treatment. HEK-293 is used to study cytotoxicity because of its reliable growth despite its karyotype complex with alterations. This makes toxicity studies more consistent (54,58-62).

Oxidative stress. The reduced glutathione and lipid peroxidation levels were observed from GSH and MDA assays, respectively. Due to the fact that the combined treatment with GNPs $(6.25 \mu \mathrm{g} / \mathrm{ml})+$ carvedilol $(3 \mu \mathrm{M})$, at $48 \mathrm{~h}$ increased the protection for HEK-293, it was observed that the levels of GSH increased statistically significantly for both HEK-293 $(\mathrm{P}<0.05)$ and HepG2 ( $\mathrm{P}<0.001)$, as shown in Fig. 4A. Cisplatin promoted reduction of GSH levels in both cell lines. Regarding lipid peroxidation for the non-tumoral lineage, there was a great reduction in malondialdehyde levels using the combined treatment with GNPs $(6.25 \mu \mathrm{g} / \mathrm{ml})+$ carvedilol $(3 \mu \mathrm{M})(\mathrm{P}<0.01)$, overcoming the control and cisplatin treated groups. This same result was observed for the HepG2 tumor cells (Fig. 4B).

Immunofluorescence of caspase-3, caspase-8, $\mathrm{Bcl}-2$ and $M A P K / E R K$. Aftercombined treatment with GNPs $(6.25 \mu \mathrm{g} / \mathrm{ml})$ + carvedilol $(3 \mu \mathrm{M})$, caspase-3 and caspase- 8 marking was noted in all treated groups (Fig. 5A). Densitometric analysis confirmed significant increases in caspase-3 ( $\mathrm{P}<0.01$; Fig. 5B), and caspase- $8(\mathrm{P}<0.001 ;$ Fig. $5 \mathrm{C})$. In addition, there was no statistically significant change in $\mathrm{Bcl}-2$ expression for the group treated with GNPs and carvedilol (Fig. 5D; P>0.05). There was a decrease in MAPK/ERK immunoreactivity in the HepG2 cells treated with GNPs and carvedilol and GNP $(6.25 \mu \mathrm{g} / \mathrm{ml})+$ carvedilol $(3 \mu \mathrm{M})$ for $48 \mathrm{~h}(\mathrm{P}<0.0001$; Fig. 5E)

Gene and protein expression by RT-PCR and western blot analysis. From the gene expression analysis, it was observed that FADD elevation was statistically significant for all groups, those treated separately with GNPs $(6.25 \mu \mathrm{g} / \mathrm{ml})$ and carvedilol $(3 \mu \mathrm{M})(\mathrm{P}<0.05)$, and in combined treatment GNPs $(6.25 \mu \mathrm{g} / \mathrm{ml})+$ carvedilol $(3 \mu \mathrm{M})(\mathrm{P}<0.01)$, yet not observed 

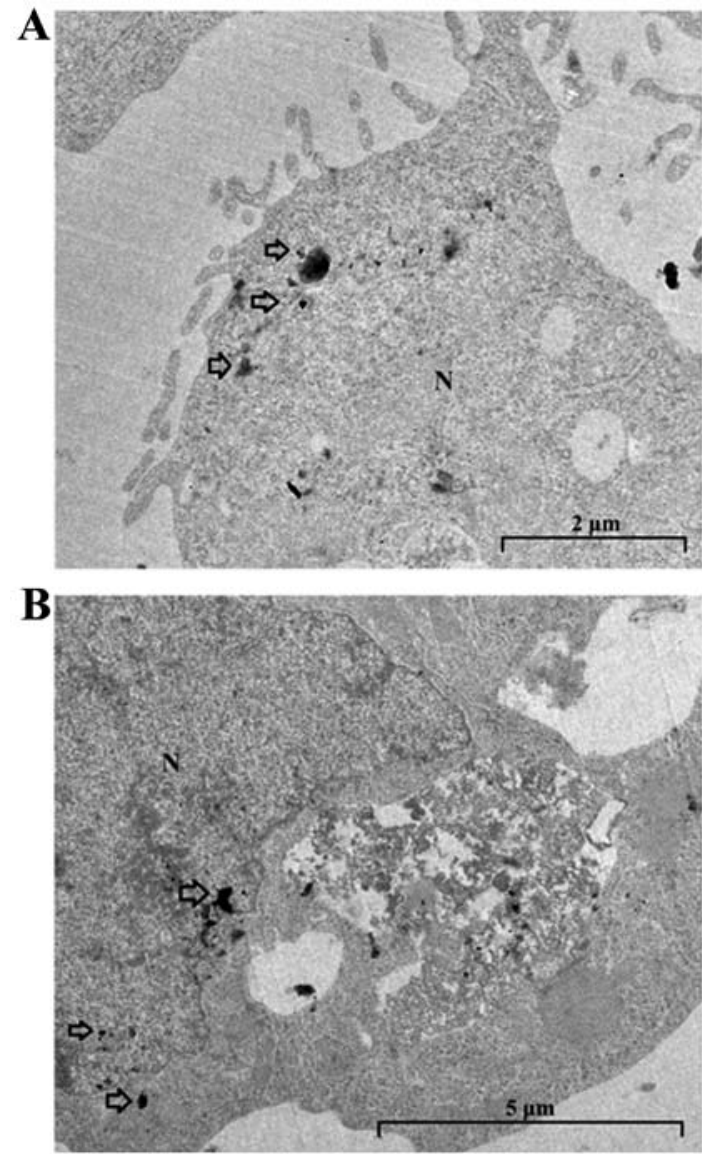

Figure 7. Transmission electron microscopy for evaluation of intracellular targets of treatment. (A) GNPs without carvedilol concentrated in the plasma membrane, indicated by black arrows. (B) For combined treatment, GNPs concentrated inside and beside the nucleus, indicated by black arrows. $\mathrm{N}$, nucleus.

for APAF-1 levels (Fig. 6A). In relation to survivin levels, no group treated with GNPs and carvedilol demonstrated a reduction, meanwhile MDR-1 levels showed statistically significant reductions for those treated with GNPs $(6.25 \mu \mathrm{g} / \mathrm{ml})$, and for combined treatment GNPs $(6.25 \mu \mathrm{g} / \mathrm{ml})+$ carvedilol $(3 \mu \mathrm{M})(\mathrm{P}<0.01$; Fig. 6B). Regarding the Akt, mTOR and EGFR levels, the groups treated with combined treatment GNPs $(6.25 \mu \mathrm{g} / \mathrm{ml})+$ carvedilol $(3 \mu \mathrm{M})$ showed statistically significant expression declines $\mathrm{P}<0.001, \mathrm{P}<0.05$ and $\mathrm{P}<0.05$, respectively (Fig. 6C). The groups treated with carvedilol (3 $\mu \mathrm{M})$ showed statistically significant reductions only for EGFR $(\mathrm{P}<0.01)$; and those treated with GNP showed statistically significant reductions only for Akt $(\mathrm{P}<0.05)$ and EGFR $(\mathrm{P}<0.05)$.

The anti-apoptotic protein levels after combined treatment of GNPs $(6.25 \mu \mathrm{g} / \mathrm{ml})+$ carvedilol $(3 \mu \mathrm{M})$ are highlighted in Fig. 6D. The results showed a large reduction of Akt and mTOR. MAPK/ERK has a good reduced protein expression when compared to the control group. $\beta$-actin was used as internal control.

Transmission electron microscopy. TEM was performed in order to ascertain locations where gold nanoparticles would concentrate, applied without carvedilol (Fig. 7A) and in combination with carvedilol (Fig. 7B). Applied alone,
GNPs $(6.25 \mu \mathrm{g} / \mathrm{ml})$ was concentrated in the vicinity of the plasma membrane. In the combined treatment with GNPs $(6.25 \mu \mathrm{g} / \mathrm{ml})+$ carvedilol $(3 \mu \mathrm{M})$, GNPs displayed intra-nuclear and perinuclear concentration.

\section{Discussion}

Data from the literature demonstrate the importance of using low doses for drug combination studies that aim to reduce side-effects and increase the field of action in different signaling pathways (63-65). In the present study, low doses of GNPs (3 and $6.25 \mu \mathrm{g} / \mathrm{ml})$ and carvedilol $(1.5$ and $3 \mu \mathrm{M})$ were selected using the cell viability test, in order to use them in combination. Studies in the literature demonstrate that low doses of GNPs are more effective in inhibiting cell proliferation than larger doses $(53,66)$. In relation to carvedilol, very high doses cause high inhibition of cell growth (67); a risk for a combined treatment. The pro-apoptotic activities of GNPs, carvedilol, and their combined use were analyzed by flow cytometry, both for tumor and non-tumoral lines. The combination of GNPs $(6.25 \mu \mathrm{g} / \mathrm{ml})+$ carvedilol $(3 \mu \mathrm{M})$ promoted significant initial and late apoptosis in hepatic tumor cells, while promoting reduction of total apoptosis in the non-tumoral lineage. Studies in the literature report the ability of GNPs to induce apoptosis in several tumor cell lines without interfering with non-tumoral lineages $(27,29,68,69)$. Carvedilol has itself also been shown to be an inducer of apoptosis in tumor cells and to protect normal cells $(36,70,71)$.

The cytoprotective effect of the combined treatment for non-cancerous cells was evidenced through GSH dosage; an important balancing antioxidant system peptide (72,73). After treatment, GSH levels were elevated, which is important for reducing oxidative stress, which is related to apoptosis induction in several tissues (74-77). In addition, GNPs and carvedilol have the ability to promote elevation of GSH levels (78-81). Furthermore, a decrease in MDA levels were evidenced, an indirect biomarker for oxidative stress, as related to plasma membrane damage (82-84). This is a significant result, since one of the main side-effects of chemotherapy is lipid peroxidation $(85,86)$.

In the tumoral lineage, we observed GSH level elevation and decreased MDA levels, demonstrating the antioxidant action of combined treatment when compared to cisplatin, which is known for its strong oxidative stress promotion $(18,19)$. This result was highly positive, since tumor cells have high rates of reactive oxygen species, which trigger the activation of proteins such as Pi3K, Akt and MAPK/ERK; responsible for both cell proliferation and survival $(87,88)$.

The pro-apoptotic activity of the treatment was confirmed by the positive immunoreactivity of caspase- 3 and caspase- 8 , proteins involved in the extrinsic apoptosis pathway (89), these were the most significant in the group treated with the combination. In addition, after treatments with GNPs $(6.25 \mu \mathrm{g} / \mathrm{ml})+$ carvedilol $(3 \mu \mathrm{M})$, there was a decrease in immunoreactivity for the MAPK/ERK, anti-apoptotic protein. A similar result is observed in western blot analysis. There were no significant changes for Bcl-2. These results indicate a prominent participation of the extrinsic apoptosis pathway, since Bcl-2 is an anti-apoptotic protein related to the intrinsic apoptosis pathway (mitochondrial) $(54,90)$. GSH elevation and 
MDA decreases, promoted by the combined treatment with GNPs $(6.25 \mu \mathrm{g} / \mathrm{ml})+$ carvedilol $(3 \mu \mathrm{M})$, may have corroborated with mitochondria protection, justifying non-activation of the intrinsic apoptosis pathway (91-96). The statistically significant elevation of FADD, mainly by combined treatment with GNPs $(6.25 \mu \mathrm{g} / \mathrm{ml})+$ carvedilol $(3 \mu \mathrm{M})$, confirms activation of the extrinsic apoptosis pathway, since it participates therein (97-99). Levels of APAF-1, a protein involved in the intrinsic pathway (100), did not present a significant differences.

The combined treatment with GNPs $(6.25 \mu \mathrm{g} / \mathrm{ml})+$ carvedilol $(3 \mu \mathrm{M})$ was extremely effective on gene expression of anti-apoptotic proteins such as Akt and mTOR, matching or overcoming the action of cisplatin. Similar effect was observed in western blot analysis. Inhibition of these proteins, as well as MAPK/ERK, is critical for induction of apoptosis $(12,51,52,101)$. Furthermore, other studies indicate that treatments with targeting of the $\mathrm{Pi} 3 \mathrm{~K} / \mathrm{Akt} / \mathrm{mTOR}$ pathway and the MAPK/ERK protein induce early and late apoptosis (102-104), as also obtained in the present study.

The decrease in EGFR levels is of great relevance since it is related to activation of Akt/mTOR and MAPK/ERK (105-108). However, it is possible that the combined treatment may be acting on EGFR-independent pathways that activate Akt and mTOR; and causing depletion (14,109-115). Levels of survivin were unchanged for treatment. However, in the same figure, there was a statistically significant reduction in MDR1 levels for both the combined treatment and the gold nanoparticles alone. Studies have shown that the use of nanoscale systems has excellent effects (this includes inorganic nanoparticles, such as gold nanoparticles), on the expression of genes related to multidrug resistance, such as MDR1 $(116,117)$. The decrease in the expression of this protein presents potential as a new strategy to combat one of the main problems of cancer treatment, resistance to treatment (118). Carvedilol, although showing no effect on MDR1 expression, has been reported in the literature as a potential MDR1 inhibitor $(119,120)$. Studies in the literature have demonstrated that treatments acting on drug resistance genes promote both early and late apoptosis (121).

TEM did reveal GNPs internalization. However, we noted that when given alone, GNPs accumulated near the plasmatic membrane. Previous studies have reported that endosomal/ lysosomal vesicles can imprison GNPs preventing complete action in the cellular interior, and are the greatest barrier that GNPs need to overcome to reach the cellular nucleus (main target) (122-125). However, after administration of carvedilol, concentration of GNPs was observed in the vicinity of the cell nucleus, both intra- and peripherally. The data possibly explain the fact that the results for GNPs administered alone show smaller indices as compared to the combined treatment, which was more effective. But even the isolated action of the gold nanoparticle can reduce, although less than combined treatment, the levels of survival and proliferation proteins such as Akt, EGFR, MDR-1 and MAPK/ERK, demonstrated in the present study, and suggest the way in which the GNPs inhibit proliferation. Concerning the combined treatment, carvedilol may be acting through other signaling pathways, or may be facilitating gold nanoparticle escape from endosomal/ lysosomal vesicles. Han et al (126) reported that carvedilol has a role during receptor recycling in endosomal/lysosomal transiting of vascular smooth muscle cell beta-adrenergic receptors.
However, there remains the need for further chemical interaction and intracellular unfolding studies.

The present study demonstrated the ability of the combined GNPs and carvedilol treatment to induce apoptosis in the tumor cells by exclusively activating the extrinsic pathway. Activation of this pathway is advantageous compared to the intrinsic pathway, since it can be triggered independently of the p53 gene, which in many tumors is inactive or absent (127). In addition, studies have demonstrated that treatments with targeting intrinsic pathway induction may also promote positive selection of tumor cells, while evading the mitochondrial pathway (128). In addition to these results, the combined treatment protected non-tumor cells, reducing oxidative stress and consequently, apoptosis. The novel findings in these studies highlight a promising alternative for future cancer treatments.

\section{Acknowledgements}

The authors are grateful to the Brain Institute (Federal University of Rio Grande do Norte), the BIOPOL (Department of Biochemistry, Federal University of Rio Grande do Norte), the Federal University of Ceará and the Leiden University Medical Center for their contributions to the present study. Universal 476996/2013-9 CNPq 2013. CAPES 88881.119850/201601. This study was also supported by the European Commission where R.F. De Araújo, A.B. Chan and L.J. Cruz have received funding from a MSCA-ITN-2015-ETN action grant (proposal no. 675743; project: ISPIC).

\section{References}

1. Hales S, Chiu A, Husain A, Braun M, Rydall A, Gagliese L, Zimmermann $\mathrm{C}$ and Rodin $\mathrm{G}$ : The quality of dying and death in cancer and its relationship to palliative care and place of death. J Pain Symptom Manage 48: 839-851, 2014.

2. Siegel RL, Miller KD and Jemal A: Cancer statistics, 2016. CA Cancer J Clin 66: 7-30, 2016.

3. Ferlay J, Soerjomataram I, Dikshit R, Eser S, Mathers C, Rebelo M, Parkin DM, Forman D and Bray F: Cancer incidence and mortality worldwide: Sources, methods and major patterns in GLOBOCAN 2012. Int J Cancer 136: E359-E386, 2015.

4. Özdemir F, Akalın G, Şen M, Önder NI, Işcan A, Kutlu HM and Incesu Z: Towards novel anti-tumor strategies for hepatic cancer: $\varepsilon$-viniferin in combination with vincristine displays pharmacodynamic synergy at lower doses in HepG2 cells. OMICS 18: 324-334, 2014.

5. Ling CQ: Problems in cancer treatment and major research of integrative medicine. Zhong Xi Yi Jie He Xue Bao 1: 168-170, 2003 (In Chinese).

6. Agrawal S: Late effects of cancer treatment in breast cancer survivors. South Asian J Cancer 3: 112-115, 2014.

7. Oberstein PE and Olive KP: Pancreatic cancer: Why is it so hard to treat? Therap Adv Gastroenterol 6: 321-337, 2013.

8. Michaelson MD, Cotter SE, Gargollo PC, Zietman AL, Dahl DM and Smith MR: Management of complications of prostate cancer treatment. CA Cancer J Clin 58: 196-213, 2008.

9. Fernald $\mathrm{K}$ and Kurokawa M: Evading apoptosis in cancer. Trends Cell Biol 23: 620-633, 2013.

10. Labi V and Erlacher M: How cell death shapes cancer. Cell Death Dis 6: e1675, 2015.

11. Ran LK, Chen Y, Zhang ZZ, Tao NN, Ren JH, Zhou L, Tang H, Chen X, Chen K, Li WY, et al: SIRT6 overexpression Potentiates apoptosis evasion in hepatocellular carcinoma via BCL2associated X protein-dependent apoptotic pathway. Clin Cancer Res 22: 3372-3382, 2016.

12. Cai Y, Tan X, Liu J, Shen Y, Wu D, Ren M, Huang P and Yu D: Inhibition of $\mathrm{PI} 3 \mathrm{~K} / \mathrm{Akt} / \mathrm{mTOR}$ signaling pathway enhances the sensitivity of the SKOV3/DDP ovarian cancer cell line to cisplatin in vitro. Chin J Cancer Res 26: 564-572, 2014. 
13. $\mathrm{Lu} \mathrm{Z}$ and Xu S: ERK1/2 MAP kinases in cell survival and apoptosis. IUBMB Life 58: 621-631, 2006.

14. Wang C, Cigliano A, Delogu S, Armbruster J, Dombrowski F, Evert M, Chen X and Calvisi DF: Functional crosstalk between AKT/mTOR and Ras/MAPK pathways in hepatocarcinogenesis: Implications for the treatment of human liver cancer. Cell Cycle 12: 1999-2010, 2013.

15. Katayama K, Noguchi K and Sugimoto Y: Regulations of P-glycoprotein/ABCB1/MDR1 in human cancer cells. New J Sci 2014: e476974, 2014

16. Yang X, Uziely B, Groshen S, Lukas J, Israel V, Russell C, Dunnington G, Formenti S, Muggia F and Press MF: MDR1 gene expression in primary and advanced breast cancer. Lab Invest 79: 271-280, 1999.

17. Chiara F, Gambalunga A, Sciacovelli M, Nicolli A Ronconi L, Fregona D, Bernardi P, Rasola A and Trevisan A: Chemotherapeutic induction of mitochondrial oxidative stress activates GSK-3 $\alpha / \beta$ and Bax, leading to permeability transition pore opening and tumor cell death. Cell Death Dis 3: e444, 2012.

18. Dasari S and Tchounwou PB: Cisplatin in cancer therapy: Molecular mechanisms of action. Eur J Pharmacol 740: 364-378, 2014.

19. Marullo R, Werner E, Degtyareva N, Moore B, Altavilla G, Ramalingam SS and Doetsch PW: Cisplatin induces a mitochondrial-ROS response that contributes to cytotoxicity depending on mitochondrial redox status and bioenergetic functions. PLoS One 8: e81162, 2013

20. Dreaden EC, Austin LA, Mackey MA and El-Sayed MA: Size matters: Gold nanoparticles in targeted cancer drug delivery. Ther Deliv 3: 457-478, 2012

21. Jain S, Hirst DG and O'Sullivan JM: Gold nanoparticles as novel agents for cancer therapy. Br J Radiol 85: 101-113, 2012.

22. Lee J, Chatterjee DK, Lee MH and Krishnan S: Gold nanoparticles in breast cancer treatment: Promise and potential pitfalls. Cancer Lett 347: 46-53, 2014

23. Alkilany AM and Murphy CJ: Toxicity and cellular uptake of gold nanoparticles: What we have learned so far? J Nanopart Res 12: 2313-2333, 2010.

24. Alvarenga ÉC Caires A, Ladeira LO, Gamero EJP, Andrade LM, Paz MTL and Leite M de F: Potenciais alvos terapêuticos contra o câncer. Cienc Cult 66: 43-48, 2014.

25. Naha PC, Chhour P and Cormode DP: Systematic in vitro toxicological screening of gold nanoparticles designed for nanomedicine applications. Toxicol In Vitro 29: 1445-1453, 2015.

26. Butterworth KT, Coulter JA, Jain S, Forker J, McMahon SJ, Schettino G, Prise KM, Currell FJ and Hirst DG: Evaluation of cytotoxicity and radiation enhancement using $1.9 \mathrm{~nm}$ gold particles: Potential application for cancer therapy. Nanotechnology 21: 295101, 2010.

27. Coulter JA, Jain S, Butterworth KT, Taggart LE, Dickson GR, McMahon SJ, Hyland WB, Muir MF, Trainor C, Hounsell AR, et al: Cell type-dependent uptake, localization, and cytotoxicity of $1.9 \mathrm{~nm}$ gold nanoparticles. Int J Nanomedicine 7: 2673-2685, 2012 .

28. Murawala P, Tirmale A, Shiras A and Prasad BLV: In situ synthesized BSA capped gold nanoparticles: Effective carrier of anticancer drug methotrexate to MCF-7 breast cancer cells. Mater Sci Eng C 34: 158-167, 2014.

29. Patra HK, Banerjee $S$, Chaudhuri U, Lahiri P and Dasgupta AK: Cell selective response to gold nanoparticles. Nanomedicine (Lond) 3: 111-119, 2007.

30. Budni P, Pedrosa RC, Dalmarco EM, Dalmarco JB, Frode TS and Wilhelm Filho D: Carvedilol enhances the antioxidant effect of vitamins $\mathrm{E}$ and $\mathrm{C}$ in chronic Chagas heart disease. Arq Bras Cardiol 101: 304-310, 2013.

31. Arozal W, Watanabe K, Veeraveedu PT,MaM,Thandavarayan RA, Sukumaran V, Suzuki K, Kodama M and Aizawa Y: Protective effect of carvedilol on daunorubicin-induced cardiotoxicity and nephrotoxicity in rats. Toxicology 274: 18-26, 2010.

32. Arumanayagam M, Chan S, Tong $S$ and Sanderson JE: Antioxidant properties of carvedilol and metoprolol in heart failure: A double-blind randomized controlled trial. J Cardiovasc Pharmacol 37: 48-54, 2001.

33. Dandona P, Ghanim H and Brooks DP: Antioxidant activity of carvedilol in cardiovascular disease. J Hypertens 25: 731-741, 2007.

34. Li YC, Ge LS, Yang PL, Tang JF, Lin JF, Chen P and Guan XQ: Carvedilol treatment ameliorates acute coxsackievirus B3-induced myocarditis associated with oxidative stress reduction. Eur J Pharmacol 640: 112-116, 2010.
35. Pasquier E, Street J, Pouchy C, Carre M, Gifford AJ, Murray J, Norris MD, Trahair T, Andre N and Kavallaris M: $\beta$-blockers increase response to chemotherapy via direct antitumour and anti-angiogenic mechanisms in neuroblastoma. Br J Cancer 108 2485-2494, 2013

36. Erguven M, Yazihan N, Aktas E, Sabanci A, Li CJ, Oktem G and Bilir A: Carvedilol in glioma treatment alone and with imatinib in vitro. Int J Oncol 36: 857-866, 2010.

37. Dezong G, Zhongbing M, Qinye F and Zhigang Y: Carvedilol suppresses migration and invasion of malignant breast cells by inactivating Src involving $\mathrm{cAMP} / \mathrm{PKA}$ and $\mathrm{PKC} \delta$ signaling pathway. J Cancer Res Ther 10: 998-1003, 2014.

38. Chang A, Yeung S, Thakkar A, Huang KM, Liu MM, Kanassatega RS, Parsa C, Orlando R, Jackson EK, Andresen BT, et al: Prevention of skin carcinogenesis by the $\beta$-blocker carvedilol. Cancer Prev Res (Phila) 8: 27-36, 2015.

39. Hsieh YD, Chi CC, Chou CT, Cheng JS, Kuo CC, Liang WZ, Lin KL, Tseng LL and Jan CR: Investigation of carvedilolevoked $\mathrm{Ca}^{2+}$ movement and death in human oral cancer cells. J Recept Signal Transduct Res 31: 220-228, 2011.

40. Cheng JS, Huang CC, Chou CT and Jan CR: Mechanisms of carvedilol-induced $\left[\mathrm{Ca}^{2+}\right]_{\mathrm{i}}$ rises and death in human hepatoma cells. Naunyn Schmiedebergs Arch Pharmacol 376: 185-194, 2007.

41. Cohen DJ and Hochster HS: Rationale for combining biotherapy in the treatment of advanced colon cancer. Gastrointest Cancer Res 2: 145-151, 2008.

42. Patutina OA, Mironova NL, Vlassov VV and Zenkova MA New approaches for cancer treatment: Antitumor drugs based on gene-targeted nucleic acids. Acta Naturae 1: 44-60, 2009.

43. Siddiqui M and Rajkumar SV: The high cost of cancer drugs and what we can do about it. Mayo Clin Proc 87: 935-943, 2012.

44. Tannock IF: Combined modality treatment with radiotherapy and chemotherapy. Radiother Oncol 16: 83-101, 1989.

45. Brito AF, Ribeiro M, Abrantes AM, Pires AS, Teixo RJ, Tralhão JG and Botelho MF: Quercetin in cancer treatment, alone or in combination with conventional therapeutics? Curr Med Chem 22: 3025-3039, 2015

46. Mierzwa ML, Nyati MK, Morgan MA and Lawrence TS: Recent advances in combined modality therapy. Oncologist 15: 372-381, 2010.

47. Li J, Wang Y,Zhu Y and Oupický D: Recent advances in delivery of drug-nucleic acid combinations for cancer treatment. J Control Release 172: 589-600, 2013.

48. Collery P, Mohsen A, Kermagoret A, D'Angelo J, Morgant G, Desmaele D, Tomas A, Collery T, Wei M and Badawi A: Combination of three metals for the treatment of cancer: Gallium, rhenium and platinum. 1. Determination of the optimal schedule of treatment. Anticancer Res 32: 2769-2781, 2012.

49. Law MR, Wald NJ, Morris JK and Jordan RE: Value of low dose combination treatment with blood pressure lowering drugs: Analysis of 354 randomised trials. BMJ 326: 1427, 2003.

50. Morton $\mathrm{CO}$, Chau $\mathrm{M}$ and Stack $\mathrm{C}$ : In vitro combination therapy using low dose clotrimazole and photodynamic therapy leads to enhanced killing of the dermatophyte Trichophyton rubrum. BMC Microbiol 14: 261, 2014.

51. Chang L, Graham PH, Ni J, Hao J, Bucci J, Cozzi PJ and Li Y: Targeting PI3K/Akt/mTOR signaling pathway in the treatment of prostate cancer radioresistance. Crit Rev Oncol Hematol 96: 507-517, 2015.

52. Chappell WH, Steelman LS, Long JM, Kempf RC, Abrams SL, Franklin RA, Bäsecke J, Stivala F, Donia M, Fagone P, et al: Ras/Raf/MEK/ERK and PI3K/PTEN/Akt/mTOR inhibitors: Rationale and importance to inhibiting these pathways in human health. Oncotarget 2: 135-164, 2011.

53. de Araújo RF, de Araújo AA, Pessoa JB, Freire Neto FP, da Silva GR, Leitão Oliveira AL, de Carvalho TG, Silva HF, Eugênio M, Sant'Anna C, et al: Anti-inflammatory, analgesic and anti-tumor properties of gold nanoparticles. Pharmacol Rep 69: 119-129, 2017.

54. de Araújo Júnior RF, Leitão Oliveira ALC, de Melo Silveira RF, de Oliveira Rocha HA, de França Cavalcanti P and de Araújo AA: Telmisartan induces apoptosis and regulates $\mathrm{Bcl}-2$ in human renal cancer cells. Exp Biol Med (Maywood) 240: 34-44, 2015.

55. Rahman I, Kode A and Biswas SK: Assay for quantitative determination of glutathione and glutathione disulfide levels using enzymatic recycling method. Nat Protoc 1: 3159-3165, 2006.

56. da Costa CM, dos Santos RC and Lima ES: A simple automated procedure for thiol measurement in human serum samples. J Bras Patol Med Lab 42: 345-350, 2006. 
57. Esterbauer $\mathrm{H}$ and Cheeseman KH: Determination of aldehydic lipid peroxidation products: Malonaldehyde and 4-hydroxynonenal. Methods Enzymol 186: 407-421, 1990.

58. Al-Sheddi ES, Al-Oqail MM, Saquib Q, Siddiqui MA, Musarrat J, Al-Khedhairy AA and Farshori NN: Novel all trans-retinoic Acid derivatives: Cytotoxicity, inhibition of cell cycle progression and induction of apoptosis in human cancer cell lines. Molecules 20: $8181-8197,2015$

59. Kimura H, Sakai K, Arao T, Shimoyama T, Tamura T and Nishio K: Antibody-dependent cellular cytotoxicity of cetuximab against tumor cells with wild-type or mutant epidermal growth factor receptor. Cancer Sci 98: 1275-1280, 2007.

60. Światek Ł, Rajtar B, Pawlak K, Ludwiczuk A, Głowniak K and Polz-Dacewicz M: In vitro evaluation of cytotoxicity of n-hexane extract from Alnus sieboldiana male flowers on VERO and HEK293 cell lines. JPCCR 7: 110-107, 2014.

61. Lapique $\mathrm{N}$ and Benenson Y: Digital switching in a biosensor circuit via programmable timing of gene availability. Nat Chem Biol 10: 1020-1027, 2014.

62. Selvaraj V, Bodapati S, Murray E, Rice KM, Winston N, Shokuhfar T, Zhao Y and Blough E: Cytotoxicity and genotoxicity caused by yttrium oxide nanoparticles in HEK293 cells. Int J Nanomed 9: 1379-1391, 2014.

63. Jia J, Zhu F, Ma X, Cao Z, Cao ZW, Li Y, Li YX and Chen YZ: Mechanisms of drug combinations: Interaction and network perspectives. Nat Rev Drug Discov 8: 111-128, 2009.

64. Richardson PG, Siegel DS, Vij R, Hofmeister CC, Baz R, Jagannath S, Chen C, Lonial S, Jakubowiak A, Bahlis N, et al: Pomalidomide alone or in combination with low-dose dexamethasone in relapsed and refractory multiple myeloma: A randomized phase 2 study. Blood 123: 1826-1832, 2014.

65. Nijhof IS, Franssen LE, Levin M-D, Bos GMJ, Broijl A, Klein SK, Koene HR, Bloem AC, Beeker A, Faber LM, et al: Phase 1/2 study of lenalidomide combined with low-dose cyclophosphamide and prednisone in lenalidomide-refractory multiple myeloma. Blood 128: 2297-2306, 2016.

66. Gatoo MA, Naseem S, Arfat MY, Dar AM, Qasim K and Zubair S: Physicochemical properties of nanomaterials: Implication in associated toxic manifestations. BioMed Res Int 2014: 498420, 2014.

67. Coelho M, Moz M, Correia G, Teixeira A, Medeiros R and Ribeiro L: Antiproliferative effects of $\beta$-blockers on human colorectal cancer cells. Oncol Rep 33: 2513-2520, 2015.

68. Baharara J, Ramezani T, Divsalar A, Mousavi M and Seyedarabi A: Induction of apoptosis by green synthesized gold nanoparticles Through activation of caspase-3 and 9 in human cervical cancer cells. Avicenna J Med Biotechnol 8: 75-83, 2016.

69. Connor EE, Mwamuka J, Gole A, Murphy CJ and Wyatt MD: Gold nanoparticles are taken up by human cells but do not cause acute cytotoxicity. Small 1: 325-327, 2005.

70. Zhao Y, Xu Y, Zhang J and Ji T: Cardioprotective effect of carvedilol: Inhibition of apoptosis in $\mathrm{H} 9 \mathrm{c} 2$ cardiomyocytes via the TLR4/NF- $\kappa \mathrm{B}$ pathway following ischemia/reperfusion injury. Exp Ther Med 8: 1092-1096, 2014.

71. Carvalho Rodrigues MA, Gobe G, Santos NA and Santos AC: Carvedilol protects against apoptotic cell death induced by cisplatin in renal tubular epithelial cells. J Toxicol Environ Health A 75: 981-990, 2012.

72. Lu SC: Glutathione synthesis. Biochim Biophys Acta 1830: 3143-3153, 2013.

73. Townsend DM, Tew KD and Tapiero H: The importance of glutathione in human disease. Biomed Pharmacother 57: 145-155, 2003.

74. Kannan K and Jain SK: Oxidative stress and apoptosis Pathophysiology 7: 153-163, 2000.

75. Takahashi A, Masuda A, Sun M, Centonze VE and Herman B: Oxidative stress-induced apoptosis is associated with alterations in mitochondrial caspase activity and Bcl-2-dependent alterations in mitochondrial pH (pHm). Brain Res Bull 62: 497-504, 2004.

76. Chang WK, Yang KD, Chuang H, Jan JT and Shaio MF: Glutamine protects activated human T cells from apoptosis by up-regulating glutathione and Bcl-2 levels. Clin Immunol 104 151-160, 2002.

77. Estrela JM, Ortega A and Obrador E: Glutathione in cancer biology and therapy. Crit Rev Clin Lab Sci 43: 143-181, 2006.

78. Zubairi MB, Ahmed JH and Al-Haroon SS: Effect of adrenergic blockers, carvedilol, prazosin, metoprolol and combination of prazosin and metoprolol on paracetamol-induced hepatotoxicity in rabbits. Indian J Pharmacol 46: 644-648, 2014.
79. Sgobbo P, Pacelli C, Grattagliano I, Villani G and Cocco T: Carvedilol inhibits mitochondrial complex I and induces resistance to $\mathrm{H}_{2} \mathrm{O}_{2}$-mediated oxidative insult in $\mathrm{H} 9 \mathrm{C} 2$ myocardial cells. Biochim Biophys Acta 1767: 222-232, 2007.

80. Barathmanikanth S, Kalishwaralal K, Sriram M, Pandian SR Youn HS, Eom S and Gurunathan S: Anti-oxidant effect of gold nanoparticles restrains hyperglycemic conditions in diabetic mice. J Nanobiotech 8: 16, 2010.

81. Yakimovich NO, Ezhevskii AA, Guseinov DV, Smirnova LA Gracheva TA and Klychkov KS: Antioxidant properties of gold nanoparticles studied by ESR spectroscopy. Russ Chem Bull 57: 520-523, 2008

82. Nielsen F, Mikkelsen BB, Nielsen JB, Andersen HR and Grandjean P: Plasma malondialdehyde as biomarker for oxidative stress: Reference interval and effects of life-style factors. Clin Chem 43: 1209-1214, 1997.

83. Gaweł S, Wardas M, Niedworok $E$ and Wardas $P$ Malondialdehyde (MDA) as a lipid peroxidation marker. Wiad Lek 57: 453-455, 2004 (In Polish)

84. Ho E, Karimi Galougahi K, Liu CC, Bhindi R and Figtree GA Biological markers of oxidative stress: Applications to cardiovascular research and practice. Redox Biol 1: 483-491, 2013.

85. Sangeetha P, Das UN, Koratkar R and Suryaprabha P: Increase in free radical generation and lipid peroxidation following chemotherapy in patients with cancer. Free Radic Biol Med 8: $15-19,1990$

86. Esfahani A, Ghoreishi Z, Nikanfar A, Sanaat Z and Ghorbanihaghjo A: Influence of chemotherapy on the lipid peroxidation and antioxidant status in patients with acute myeloid leukemia. Acta Med Iran 50: 454-458, 2012.

87. Cabello CM, Bair WB III and Wondrak GT: Experimental therapeutics: Targeting the redox Achilles heel of cancer. Curr Opin Investig Drugs 8: 1022-1037, 2007.

88. Liou GY and Storz P: Reactive oxygen species in cancer. Free Radic Res 44: 479-496, 2010.

89. García M and Vecino E: Vías de señalización intracelular que conducen a la apoptosis de las células de la retina. Arch Soc Esp Oftalmol 78: 351-364, 2003

90. Kang MH and Reynolds CP: Bcl-2 inhibitors: Targeting mitochondrial apoptotic pathways in cancer therapy. Clin Cancer Res 15: 1126-1132, 2009.

91. Ahmad S, White CW, Chang LY, Schneider BK and Allen CB Glutamine protects mitochondrial structure and function in oxygen toxicity. Am J Physiol Lung Cell Mol Physiol 280: L779-L791, 2001.

92. Drake J, Sultana R, Aksenova M, Calabrese V and Butterfield DA: Elevation of mitochondrial glutathione by gamma-glutamylcysteine ethyl ester protects mitochondria against peroxynitrite-induced oxidative stress. J Neurosci Res 74: 917-927, 2003.

93. Marí M, Morales A, Colell A, García-Ruiz C and FernándezCheca JC: Mitochondrial glutathione, a key survival antioxidant. Antioxid Redox Signal 11: 2685-2700, 2009.

94. Cheng J, Wang F, Yu DF, Wu PF and Chen JG: The cytotoxic mechanism of malondialdehyde and protective effect of carnosine via protein cross-linking/mitochondrial dysfunction/ reactive oxygen species/MAPK pathway in neurons. Eur J Pharmacol 650: 184-194, 2011

95. Ayala A, Muñoz MF and Argüelles S: Lipid peroxidation: Production, metabolism, and signaling mechanisms of malondialdehyde and 4-hydroxy-2-nonenal. Oxid Med Cell Longev 2014: 360438, 2014.

96. Qin J, Kang Y, Xu Z, Zang C, Fang B and Liu X: Dioscin prevents the mitochondrial apoptosis and attenuates oxidative stress in cardiac H9c2 cells. Drug Res (Stuttg) 64: 47-52, 2014.

97. Bang S, Jeong EJ, Kim IK, Jung YK and Kim KS: Fas- and tumor necrosis factor-mediated apoptosis uses the same binding surface of FADD to trigger signal transduction. A typical model for convergent signal transduction. J Biol Chem 275 36217-36222, 2000.

98. Osborn SL, Sohn SJ and Winoto A: Constitutive phosphorylation mutation in Fas-associated death domain (FADD) results in early cell cycle defects. J Biol Chem 282: 22786-22792, 2007.

99. Xerri L, Devilard E, Bouabdallah R, Stoppa AM, Hassoun J and Birg F: FADD expression and caspase activation in B-cell lymphomas resistant to Fas-mediated apoptosis. Br J Haematol 106: 652-661, 1999.

100. Campioni M, Santini D, Tonini G, Murace R, Dragonetti E, Spugnini EP and Baldi A: Role of Apaf-1, a key regulator of apoptosis, in melanoma progression and chemoresistance. Exp Dermatol 14: 811-818, 2005. 
101. Brazil DP, Yang ZZ and Hemmings BA: Advances in protein kinase B signalling: AKTion on multiple fronts. Trends Biochem Sci 29: 233-242, 2004.

102. Daniele S, Costa B, Zappelli E, Da Pozzo E, Sestito S, Nesi G, Campiglia P, Marinelli L, Novellino E, Rapposelli S, et al: Combined inhibition of AKT/mTOR and MDM2 enhances glioblastoma multiforme cell apoptosis and differentiation of cancer stem cells. Sci Rep 5: 9956, 2015.

103. Li C, Xin P, Xiao H, Zheng Y, Huang Y and Zhu X: The dual $\mathrm{PI} 3 \mathrm{~K} / \mathrm{mTOR}$ inhibitor NVP-BEZ235 inhibits proliferation and induces apoptosis of burkitt lymphoma cells. Cancer Cell Int 15: $65,2015$.

104. Liu Z, Ruan HJ, Gu PQ, Ding WY, Luo XH, Huang R, Zhao W and Gao LJ: The roles of p38 MAPK and ERK1/2 in coplanar polychlorinated biphenyls-induced apoptosis of human extravillous cytotrophoblast-derived transformed cells. Cell Physiol Biochem 36: 2418-2432, 2015.

105. Freudlsperger C, Burnett JR, Friedman JA, Kannabiran VR, Chen Z and Van Waes C: EGFR-PI3K-AKT-mTOR signaling in head and neck squamous cell carcinomas: Attractive targets for molecular-oriented therapy. Expert Opin Ther Targets 15: 63-74, 2011.

106. Gan Y, Shi C, Inge L, Hibner M, Balducci J and Huang Y: Differential roles of ERK and Akt pathways in regulation of EGFR-mediated signaling and motility in prostate cancer cells. Oncogene 29: 4947-4958, 2010.

107. Seshacharyulu P, Ponnusamy MP, Haridas D, Jain M, Ganti AK and Batra SK: Targeting the EGFR signaling pathway in cancer therapy. Expert Opin Ther Targets 16: 15-31, 2012.

108. Kidger AM and Keyse SM: The regulation of oncogenic Ras/ERK signalling by dual-specificity mitogen activated protein kinase phosphatases (MKPs). Semin Cell Dev Biol 50: 125-132, 2016.

109. Gao Y, Moten A and Lin HK: Akt: A new activation mechanism. Cell Res 24: 785-786, 2014.

110. Liu P, Begley M, Michowski W, Inuzuka H, Ginzberg M, Gao D, Tsou P, Gan W, Papa A, Kim BM, et al: Cell-cycle-regulated activation of Akt kinase by phosphorylation at its carboxyl terminus. Nature 508: 541-545, 2014.

111. Aeder SE, Martin PM, Soh JW and Hussaini IM: PKC-eta mediates glioblastoma cell proliferation through the Akt and mTOR signaling pathways. Oncogene 23: 9062-9069, 2004.

112. Fan QW, Cheng C, Knight ZA, Haas-Kogan D, Stokoe D, James CD, McCormick F, Shokat KM and Weiss WA: EGFR signals to mTOR through PKC and independently of Akt in glioma. Sci Signal 2: ra4, 2009.

113. Mendoza MC, Er EE and Blenis J: The Ras-ERK and PI3K-mTOR pathways: Cross-talk and compensation. Trends Biochem Sci 36: 320-328, 2011.

114. Denduluri SK, Idowu O, Wang Z, LiaoZ, Yan Z, Mohammed MK, Ye J, Wei Q, Wang J, Zhao L, et al: Insulin-like growth factor (IGF) signaling in tumorigenesis and the development of cancer drug resistance. Genes Dis 2: 13-25, 2015.
115. Farabaugh SM, Boone DN and Lee AV: Role of IGF1R in breast cancer subtypes, stemness and lineage differentiation. Front Endocrinol (Lausanne) 6: 59, 2015

116. Kapse-Mistry S, Govender T, Srivastava R and Yergeri M: Nanodrug delivery in reversing multidrug resistance in cancer cells. Front Pharmacol 5: 159, 2014.

117. Salomon JJ and Ehrhardt C: Nanoparticles attenuate P-glycoprotein/MDR1 function in A549 human alveolar epithelial cells. Eur J Pharm Biopharm 77: 392-397, 2011.

118. Callaghan R, Luk F and Bebawy M: Inhibition of the multidrug resistance P-glycoprotein: Time for a change of strategy? Drug Metab Dispos 42: 623-631, 2014.

119. Kakumoto M, Sakaeda T, Takara K, Nakamura T, Kita T, Yagami T, Kobayashi H, Okamura N and Okumura K: Effects of carvedilol on MDR1-mediated multidrug resistance: Comparison with verapamil. Cancer Sci 94: 81-86, 2003.

120. Wessler JD, Grip LT, Mendell J and Giugliano RP: The P-glycoprotein transport system and cardiovascular drugs. J Am Coll Cardiol 61: 2495-2502, 2013.

121. Mitsiades CS, Treon SP, Mitsiades N, Shima Y, Richardson P, Schlossman R, Hideshima T and Anderson KC: TRAIL/Apo2L ligand selectively induces apoptosis and overcomes drug resistance in multiple myeloma: Therapeutic applications. Blood 98: 795-804, 2001.

122. Huang X, Kang B, Qian W, Mackey MA, Chen PC, Oyelere AK, El-Sayed IH and El-Sayed MA: Comparative study of photothermolysis of cancer cells with nuclear-targeted or cytoplasm-targeted gold nanospheres: Continuous wave or pulsed lasers. J Biomed Opt 15: 058002, 2010.

123. Yang CJ and Chithrani DB: Nuclear targeting of gold nanoparticles for improved therapeutics. Curr Top Med Chem 16: 271-280, 2016.

124. Kodiha M, Wang YM, Hutter E, Maysinger D and Stochaj U: Off to the organelles - killing cancer cells with targeted gold nanoparticles. Theranostics 5: 357-370, 2015.

125. Yanes RE, Tarn D, Hwang AA, Ferris DP, Sherman SP, Thomas CR, Lu J, Pyle AD, Zink JI and Tamanoi F: Involvement of lysosomal exocytosis in the excretion of mesoporous silica nanoparticles and enhancement of the drug delivery effect by exocytosis inhibition. Small 9: 697-704, 2013.

126. Han SO, Xiao K, Kim J, Wu JH, Wisler JW, Nakamura N, Freedman NJ and Shenoy SK: MARCH2 promotes endocytosis and lysosomal sorting of carvedilol-bound $\beta_{2}$-adrenergic receptors. J Cell Biol 199: 817-830, 2012.

127. El-Deiry WS: Insights into cancer therapeutic design based on p53 and TRAIL receptor signaling. Cell Death Differ 8: 1066-1075, 2001.

128. Sayers TJ: Targeting the extrinsic apoptosis signaling pathway for cancer therapy. Cancer Immunol Immunother 60: 1173-1180, 2011. 